This item was submitted to Loughborough's Research Repository by the author.

Items in Figshare are protected by copyright, with all rights reserved, unless otherwise indicated.

\title{
Atropo- and diastereoselective construction of tetracyclic biphenylazepinium salts derived from aminoalcohols: use as catalysts in enantioselective asymmetric epoxidation.
}

\section{PLEASE CITE THE PUBLISHED VERSION}

http://dx.doi.org/10.1021/acs.joc.5b01157

\section{PUBLISHER}

(c) American Chemical Society

\section{VERSION}

AM (Accepted Manuscript)

\section{PUBLISHER STATEMENT}

This work is made available according to the conditions of the Creative Commons Attribution-NonCommercialNoDerivatives 4.0 International (CC BY-NC-ND 4.0) licence. Full details of this licence are available at: https://creativecommons.org/licenses/by-nc-nd/4.0/

\section{LICENCE}

CC BY-NC-ND 4.0

\section{REPOSITORY RECORD}

Page, Philip C. Bulman, Christopher A. Pearce, Yohan Chan, Phillip Parker, Benjamin R. Buckley, Gerasimos A. Rassias, and Mark R.J. Elsegood. 2019. "Atropo- and Diastereoselective Construction of Tetracyclic Biphenylazepinium Salts Derived from Aminoalcohols: Use as Catalysts in Enantioselective Asymmetric Epoxidation.". figshare. https://hdl.handle.net/2134/18878. 


\title{
Atropo- and diastereo- selective construction of tetracyclic biphenylazepinium salts
} derived from aminoalcohols: Use as catalysts in enantioselective asymmetric epoxidation

\author{
Philip C. Bulman Page, ${ }^{\mathrm{a} *}$ Christopher A. Pearce, ${ }^{\mathrm{a}}$ Yohan Chan, ${ }^{\mathrm{a}}$ Phillip Parker, ${ }^{\mathrm{b}}$ Benjamin R. \\ Buckley, ${ }^{\mathrm{b}}$ Gerasimos A. Rassias, ${ }^{\mathrm{c}}$ and Mark R. J. Elsegood ${ }^{\mathrm{b}}$ \\ ${ }^{a}$ School of Chemistry, University of East Anglia, Norwich Research Park, Norwich, Norfolk NR4 7TJ, UK \\ ${ }^{b}$ Chemistry Department, Loughborough University, Loughborough, Leicestershire LE11 3TU, UK \\ ${ }^{c}$ Department of Chemistry, University of Patras, 26504 Patras, Greece
}

p.page@uea.ac.uk

\begin{abstract}
A range of new biphenylazepinium salt organocatalysts effective for asymmetric epoxidation has been developed incorporating an additional substituted oxazolidine ring, and providing improved enantiocontrol in alkene epoxidation over the parent structure. Starting from enantiomerically pure amino-alcohols, tetracyclic iminium salts were obtained as single diastereoisomers through an atroposelective oxazolidine formation.
\end{abstract}

\section{Introduction}

Epoxides are versatile building blocks widely used in synthesis. ${ }^{1}$ The past thirty years have seen the development of many methodologies capable of efficient asymmetric epoxidation of various types of alkene. ${ }^{2}$ Dioxiranes, ${ }^{3}$ and oxaziridinium salts, first reported by Lusinchi, ${ }^{4}$ and generated in situ from the corresponding iminium salts ${ }^{5}$ or amines, ${ }^{6}$ have proven to be two of the most effective types of organocatalyst for asymmetric oxygen transfer to weakly nucleophilic substrates such as unfunctionalized alkenes. Over the past ten years we have developed a range of enantiopure iminium salts effective as organocatalysts for highly enantioselective asymmetric epoxidation in the presence of Oxone as stoicheiometric oxidant. We have reported that the most reactive and selective iminium salt catalysts discovered to date are based on $(S, S)$-acetonamine derivative $\mathbf{1}$ and a biphenyl backbone such as 2, 3 and 4, or a binaphthyl backbone such as 5. For example, iminium species 2a catalyses the oxidation of 1-phenylcyclohexene to its corresponding epoxide in less than 4 minutes inducing up to $60 \%$ enantioselectivity, ${ }^{7}$ while catalyst $\mathbf{5 a}$ affords the same epoxide in $91 \%$ ee after 15 min. ${ }^{8}$ The use of alternative oxidants, such as bleach or hydrogen peroxide, has also been explored, ${ }^{9}$ and the successful development of non-aqueous conditions using tetraphenylphosphonium 
monoperoxysulfate $^{10}$ (TPPP) has allowed us to access highly enantioenriched epoxides (up to 99\% ee). ${ }^{11}$<smiles>CC1(C)OC[C@@H](N)[C@H](c2ccccc2)O1</smiles>

1

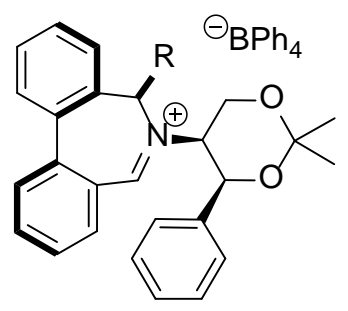

$2 a \mathrm{R}=\mathrm{H}$

2b R= Me

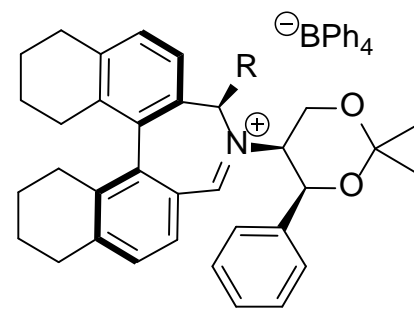

$4 a \mathrm{R}=\mathrm{H}$

4b $\mathrm{R}=\mathrm{Me}$

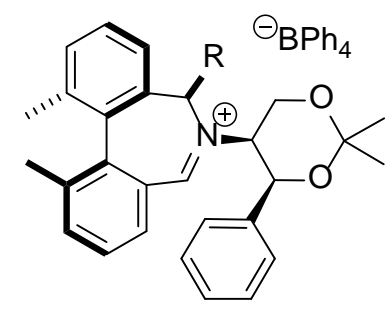

3a $\mathrm{R}=\mathrm{H}$

3b $\mathrm{R}=\mathrm{Me}$

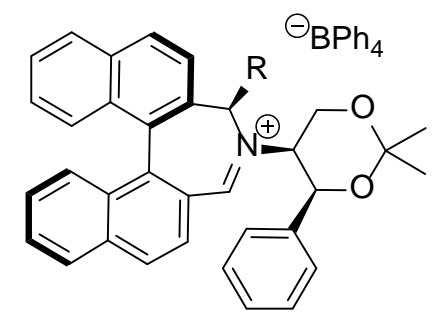

$5 a \mathrm{R}=\mathrm{H}$

$5 b \mathrm{R}=\mathrm{Me}$

Figure 1. Iminium salt catalysts for asymmetric epoxidation

A potential issue concerning cyclic biaryl structures is their ability to rotate through the aryl/aryl bond generating two interconverting atropoisomers. ${ }^{12}$ Using biaryl azepine 6 as a model substrate, Wallace showed that asymmetric introduction of an alkyl group at C(7) could induce a strong conformational preference for one atropoisomer. ${ }^{13}$ Lacour has used derivatization at the 3,3'positions on the aromatic rings to prevent such interconversion, as in $\mathbf{3 a} / \mathbf{3 b}{ }^{14}$ We have shown that the introduction of an axial substituent at the $\mathrm{C}(7)$ position by nucleophilic addition to $2 \mathrm{a}$ to create a new chiral centre adjacent to the iminium nitrogen, followed by reoxidation, generates 'second generation' iminium salt catalysts such as $\mathbf{2 b}, \mathbf{3 b}, \mathbf{4 b}$ and $\mathbf{5 b}$, which provide increased enantiocontrol in the epoxidation of alkene substrates. ${ }^{15}$

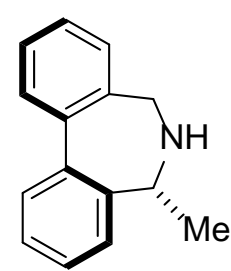

6<smiles>C[C@]12OC[C@@H](c3ccccc3)N1C(=O)c1ccccc1-c1ccccc12</smiles>

7

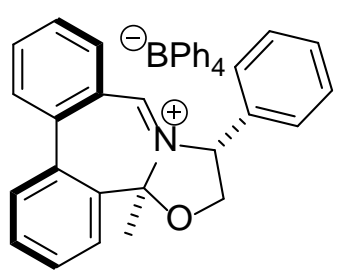

8

Meyers' bicyclic lactam methodology has been widely used in the stereoselective construction of five-, six- and seven-membered ring nitrogen heterocycles from enantiopure amino alcohols. ${ }^{16}$ 
Particularly of interest to us, the methodology has been applied to prepare a range of axially chiral biaryl lactams such as $7 .^{17}$ We postulated that structurally related iminium salts such as 8 might impart increased levels of enantioselectivity when used as an asymmetric epoxidation catalyst by imparting additional rigidity and structural elements in the transition state compared to catalysts such as 4 .

\section{Results and Discussion}

Our initial hypothesis was that the 7,5-fused bicyclic lactam sub-structure 7 could be used to generate amine $\mathbf{9}$, a suitable precursor to iminium species $\mathbf{8}$, by reduction of the lactam unit (Scheme 1). However, reduction of compound $\mathbf{7}$ is known to lead to amino-alcohol $\mathbf{1 0}$ using literature procedures. ${ }^{18}$ We have previously shown that oxidation of such azepines occurs preferentially at the least substituted adjacent position, ruling out the possibility to use this pathway, because $\mathbf{1 0}$ would not be oxidized to $\mathbf{1 1} .{ }^{15}$ We therefore devised an alternative pathway based upon a biaryl coupling of a suitably functionalized oxazolidinone using an adaptation of Fagnou's methodology ${ }^{19}$ by Wallace (Scheme 1). ${ }^{20}$ Synthesis of the cyclization precursor 12 would be achieved by Suzuki-Miyaura coupling of a suitably functionalized amino-alcohol 14 with 2-acetylphenylboronic acid to give 13, and subsequent hydrolysis of the oxazolidinone protecting group. Cyclocondensation of $\mathbf{1 2}$ to form the iminium species $\mathbf{1 1}$ would result in concomitant cyclization to the oxazolidine $\mathbf{9}$ by intramolecular attack of the hydroxyl group. We have previously observed diastereoselective formation of oxazolidines in a related binaphthyl system when generating iminium species bearing an alcohol moiety. ${ }^{21}$ Finally, oxidation of $\mathbf{9}$ under our standard conditions would give iminium salt catalyst 8.

This methodology would allow the use of a wide variety of enantiomerically pure amino-alcohol precursors. Accordingly, alkylation of $(R)$-phenyl oxazolidinone 15 with 2-iodobenzylbromide afforded $N$-substituted oxazolidinone 14 in 98\% yield. $N$-Benzyl oxazolidinone 14 was coupled with 2-acetylphenyl boronic acid under conditions used by Levacher. ${ }^{17 a}$ Hydrolysis of the crude oxazolidinone $\mathbf{1 3}$ was completed with aqueous sodium hydroxide in dichloromethane; the solvent was removed and tert-butylmethyl ether (TBME) added. The resulting solution of aminoalcohol 12 was treated with aqueous $\mathrm{HCl}$ to generate the desired tetracyclic amine $\mathbf{9}$ via $\mathbf{1 1}$ as a single diastereoisomer in $12 \%$ yield over the three steps. Finally, the iminium salt $\mathbf{8}$ was generated by oxidation of the amine using NBS in chloroform in $80 \%$ yield. 


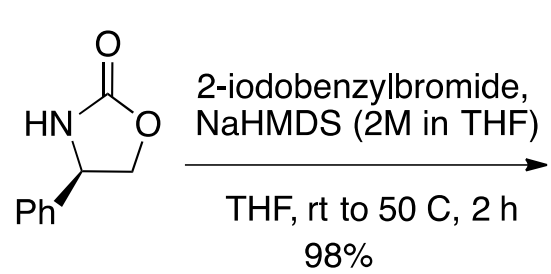<smiles>O=C1OCC(c2ccccc2)N1Cc1ccccc1I</smiles>

15

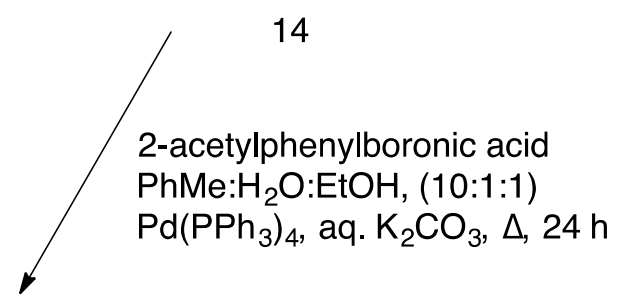

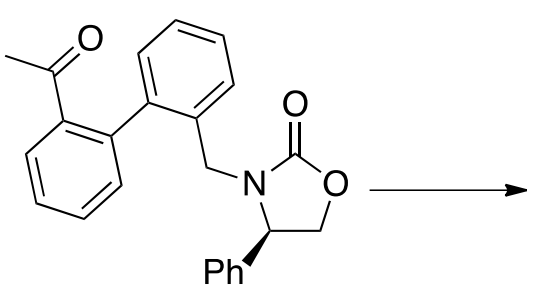

13<smiles>CC(=O)c1ccccc1-c1ccccc1CNC(CO)c1ccccc1</smiles>

12

aq. $\mathrm{NaOH}, \mathrm{CH}_{2} \mathrm{Cl}_{2}, \Delta, 16 \mathrm{~h}$;

$\mathrm{HCl}$, TBME, $\Delta, 30 \mathrm{~min}$

$12 \%$ (three steps)<smiles></smiles>

8

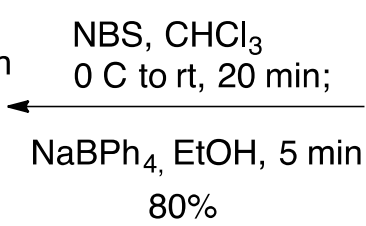
$80 \%$<smiles>C[C@]12OC[C@H](c3ccccc3)N1C(=O)c1ccccc1-c1ccccc12</smiles>

7<smiles>Cc1ccccc1-c1ccccc1-c1ccccc1CN1Cc2ccccc2O1</smiles>

9<smiles>CC1=NCc2ccccc2-c2ccccc21</smiles>

11<smiles>C[C@H]1c2ccccc2-c2ccccc2CN1[C@H](CO)c1ccccc1</smiles>

10

Scheme 1

We tested iminium salt 8 for its efficacy as an epoxidation catalyst, using 1-phenylcyclohexene as our test substrate under our standard Oxone oxidative conditions. Catalyst 8 gave 100\% conversion within thirty minutes, imparting a fair 55\% ee for 1-phenylcyclohexene oxide (Scheme 2). 
<smiles>C1=C(c2ccccc2)CCCC1</smiles>

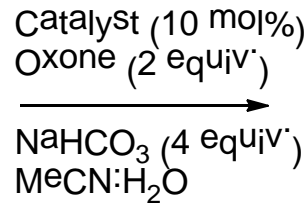

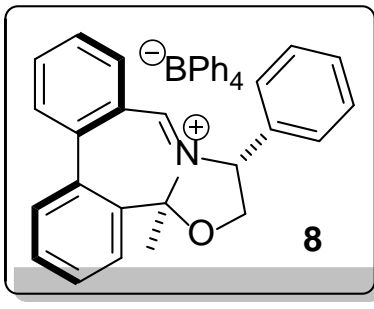

$100 \%$ conv $55 \%$ ee

\section{Scheme 2}

While this result established a new sub-structure of iminium salts active for the catalytic asymmetric epoxidation of alkenes, the overall yield of this synthetic route, particularly in the conversion of 14 into 9, coupled with the problematic purification of the unstable oxazolidinone $\mathbf{1 3}$ led us to seek an alternative.

We reasoned that a change of aminoalcohol protecting group from oxazolidinone to a much more readily hydrolysed oxaminal might improve the process, and so targeted dimethyloxazolidine 18 (Scheme 3). Reductive amination of 2-iodobenzaldehyde with $(R)$-phenyl glycinol 16 gave the $N$ benzyl amino alcohol 17 in $81 \%$ yield. Protection of the aminoalcohol functionality with dimethoxypropane gave the oxazolidine 18 in 96\% yield. 


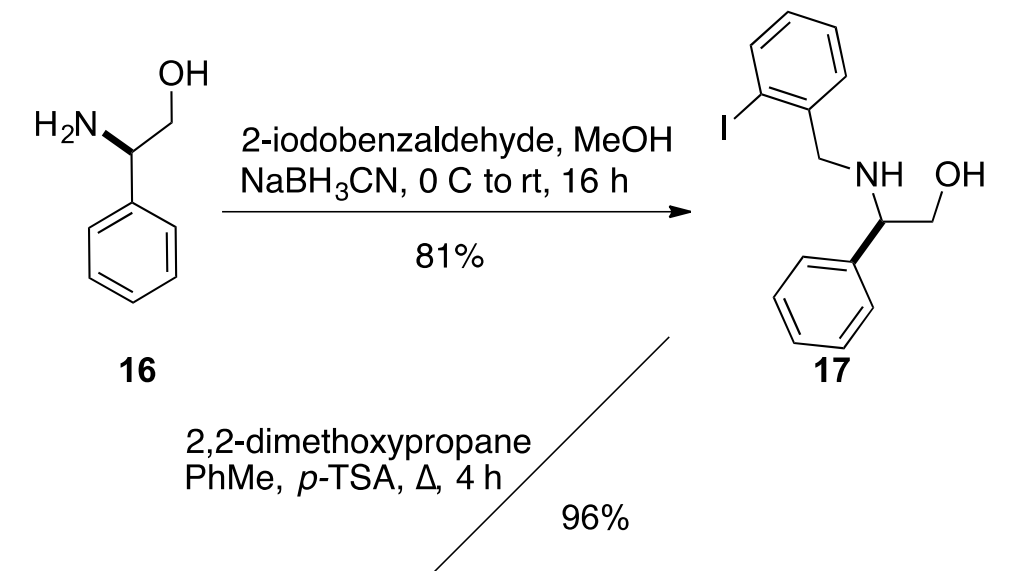

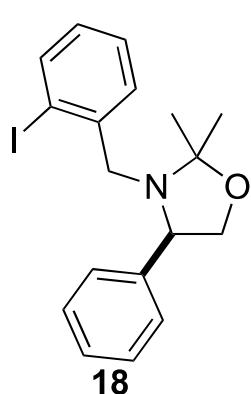

$40 \%$

9

Single diastereoisomer 2-acetylphenylboronic acid $\mathrm{PhMe}: \mathrm{H}_{2} \mathrm{O}: \mathrm{EtOH}$ $\mathrm{Pd}\left(\mathrm{PPh}_{3}\right)_{4}$, aq. $\mathrm{K}_{2} \mathrm{CO}_{3}, \Delta, 24 \mathrm{~h}$

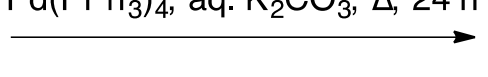

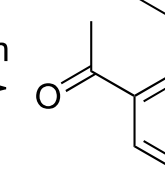<smiles>C=CC</smiles>

19<smiles>c1ccc([C@H]2CO[C@]3(c4ccccc4)c4ccccc4-c4ccccc4CN23)cc1</smiles>

9

Single diastereoisomer

Oxazolidine 18 was coupled with 2-acetylphenylboronic acid under the conditions described above. Attempted purification using column chromatography on silica gel of the crude coupled product led to the isolation of a mixture of two inseparable compounds. Upon inspection of the ${ }^{1} \mathrm{H}$ NMR spectrum of the mixture, the two products were identified as the desired Suzuki adduct $\mathbf{1 9}$ and the target tetracyclic 6,6,7,5 material $\mathbf{9}$ as a single diastereoisomer.

Following our conjecture that silica gel had effected a deprotection to expose the aminoalcohol, which then condensed in situ with the pendent ketone generating the desired tetracycle, we subjected the crude reaction mixture from the Suzuki coupling to silica gel in chloroform over $15 \mathrm{~h}$ (Scheme 3), so generating tetracycle 9 as a single diastereoisomer in a somewhat improved $40 \%$ yield. The absolute configuration of $\mathbf{9}$ was confirmed by single crystal X-ray analysis. The tetracylic tertiary 
amine 9 was readily converted into iminium salt $\mathbf{8}$ in $80 \%$ yield. To test the need for the protection/deprotection steps, a Suzuki coupling between unprotected amino-alcohol 17 and 2acetylphenylboronic acid was attempted.

Anticipating the deactivation of the palladium-phosphine catalyst by the aminoalcohol, we expected to observe poor conversion. To our delight, however, we observed the Suzuki coupling followed by in situ intramolecular cyclization, generating the 6,6,7,5-tetracyclic core $\mathbf{9}$ as a single diastereoisomer in $40 \%$ yield (Scheme 4).
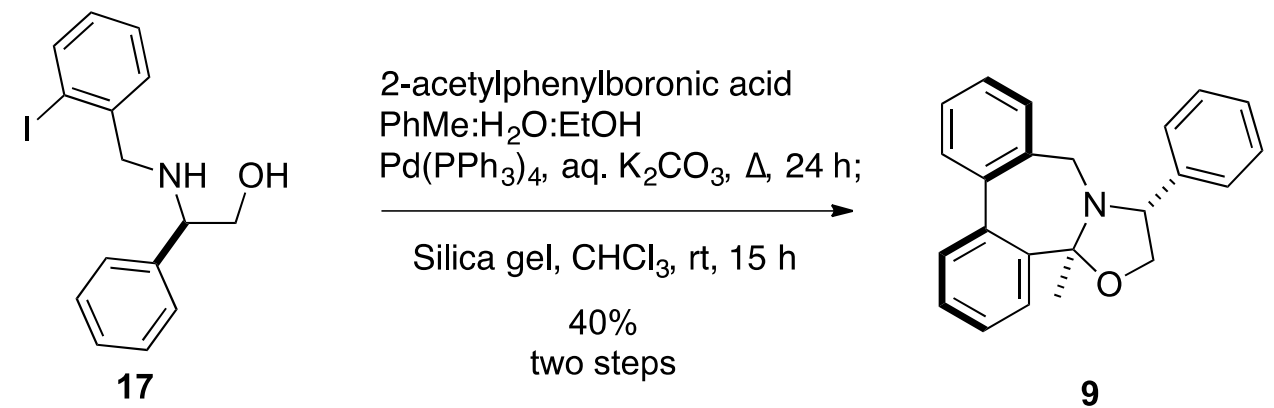

\section{Scheme 4}

The phenyl substituted azepinium bromide salt 8 was thus obtained in just four steps in 26\% overall yield from $(R)$-phenyl glycinol 16. A number of aminoalcohols - (S)-alaninol, (S)-valinol, and (R)- \& (S)-phenylalaninol - were subjected to the same reaction sequence to prepare a selection of potential catalysts with different substituents at the oxazolidine ring, to give the cyclized products $\mathbf{8}$ and $\mathbf{2 8}$ 31, each again generated as single diastereoisomers (Table 1; Figure 2).

Table 1. Isolated yields of the key intermediates in generating six tetracyclic iminium salt catalysts

\begin{tabular}{|c|c|c|c|}
\hline & \\
\hline $\mathrm{R}=(S)-\mathrm{Me}$ & $83 \%(\mathbf{2 0})$ & $22 \%(\mathbf{2 4})$ & $74 \%(\mathbf{2 8})$ \\
\hline $\mathrm{R}=(S)-\mathrm{Pr}$ & $16 \%(\mathbf{2 1})$ & $47 \%(\mathbf{2 5})$ & $81 \%(\mathbf{2 9})$ \\
\hline $\mathrm{R}=(R)-\mathrm{Ph}$ & $81 \%(\mathbf{1 7})$ & $40 \%(\mathbf{9})$ & $80 \%(\mathbf{8})$ \\
\hline $\mathrm{R}=(R)-\mathrm{Bn}$ & $90 \%(\mathbf{2 2})$ & $60 \%(\mathbf{2 6})$ & $82 \%(\mathbf{3 0})$ \\
\hline $\mathrm{R}=(S)-\mathrm{Bn}$ & $86 \%(\mathbf{2 3})$ & $30 \%(\mathbf{2 7})$ & $75 \%(\mathbf{3 1})$ \\
\hline
\end{tabular}




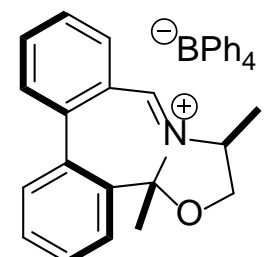

28

$13 \%$ overall yield

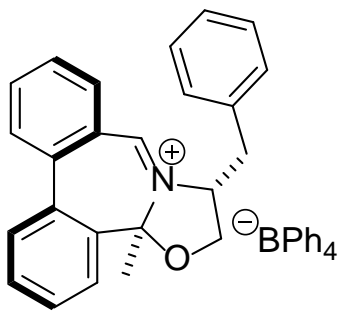

30

$44 \%$ overall yield

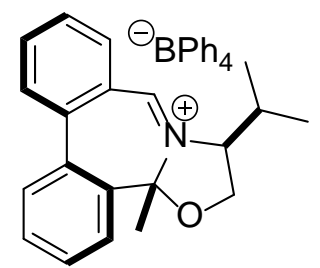

29

$6 \%$ overall yield<smiles>C[C@]12OC[C@@H](Cc3ccccc3)N1Cc1ccccc1-c1ccccc12</smiles>

31

$19 \%$ overall yield<smiles>C[C@]12OC[C@@H](c3ccccc3)N1Cc1ccccc1-c1ccccc12</smiles>

8

Figure 2. New iminium salts

Single crystal X-ray structure determination carried out on the (R)-phenyl 9 and (S)-benzyl 27 derivatives (Figure 3) show the cis-relationship between the methyl groups and the oxazolidine ring phenyl and benzyl substituents derived from the parent aminoalcohols, the pseudo-equatorial placement of these phenyl and benzyl substituents, the axial orientation of the methyl groups, and the chirality of the atropoisomeric biaryl units.

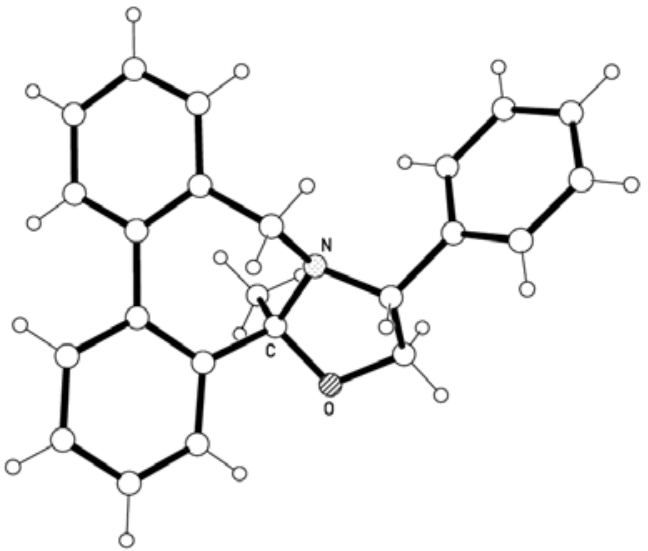

$(a R, 3 R, 13 b S)$-amine 9

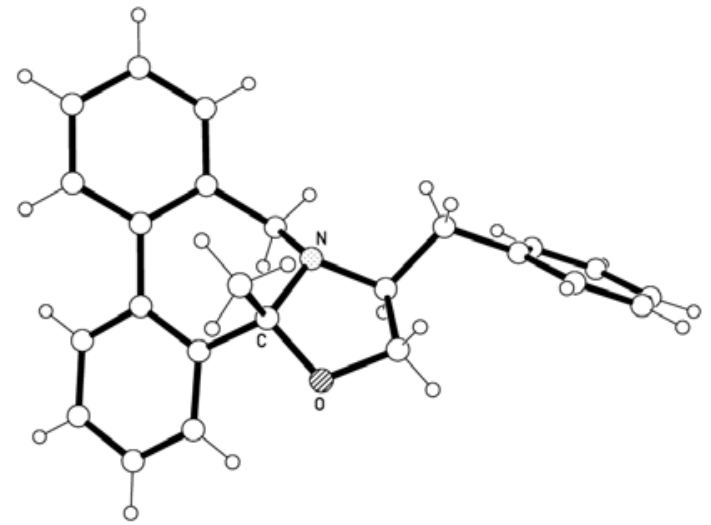

(aS,3S,13bR)-amine 27

Figure 3. Single crystal X-ray structural determination of $\mathbf{9}$ and $\mathbf{2 7}$

The stereoselectivity of the cyclization of the aminoalcohol functionality in the intermediate iminium species 11 may be driven by preferred placement of the smaller methyl substituent in the pseudoaxial orientation (Scheme 5), perhaps through an equilibrium process. ${ }^{17 \mathrm{a}}$ 
<smiles>CC(=O)c1ccccc1CNC(CO)c1ccccc1</smiles>

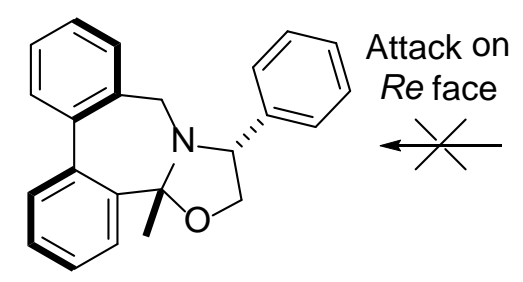<smiles>CC1=C(C)c2ccccc2-c2ccccc2C1</smiles><smiles>CC(C)Oc1cccc2c1-c1ccccc1[C@]1(C)CN2[C@@H](c2ccccc2)CO1</smiles>

Scheme 5

Catalysts $\mathbf{8}$ and 28-31 were tested for catalytic activity under our standard conditions using oxone as oxidant, and compared to the simple biphenyl azepinium catalyst 2a (Table 2).

Table 2. Asymmetric Epoxidation of a range of alkenes by catalysts 8 and 28-31

\begin{tabular}{|c|c|c|c|c|}
\hline Epoxide & Catalyst & Conversion $/ \%{ }^{\mathrm{c}, \mathrm{d}}$ & ee $/ \%{ }^{b, c}$ & Major enantiomer ${ }^{f}$ \\
\hline & $2 a$ & 100 & 60 & $(-)-1 S, 2 S$ \\
\hline & 8 & 100 & 55 & $(+) 1 R, 2 R$ \\
\hline & 28 & 100 & 30 & $(-)-1 S, 2 S$ \\
\hline & 29 & 100 & 30 & $(-)-1 S, 2 S$ \\
\hline & 30 & 100 & 64 & $(+) 1 R, 2 R$ \\
\hline & 31 & 100 & 64 & $(-)-1 S, 2 S$ \\
\hline & $2 a$ & 100 & 32 & $(+) 1 S, 2 R$ \\
\hline & 8 & 100 & 76 & $(-) 1 R, 2 S$ \\
\hline & 30 & 100 & 46 & $(-) 1 R, 2 S$ \\
\hline & 31 & 100 & 47 & $(+) 1 S, 2 R$ \\
\hline & $2 a$ & 34 & 41 & $(-) 1 R, 2 S$ \\
\hline & 8 & 20 & 64 & $(+) 1 S, 2 R$ \\
\hline & 30 & 47 & 52 & $(+) 1 S, 2 R$ \\
\hline & 31 & 39 & 55 & $(-) 1 R, 2 S$ \\
\hline
\end{tabular}




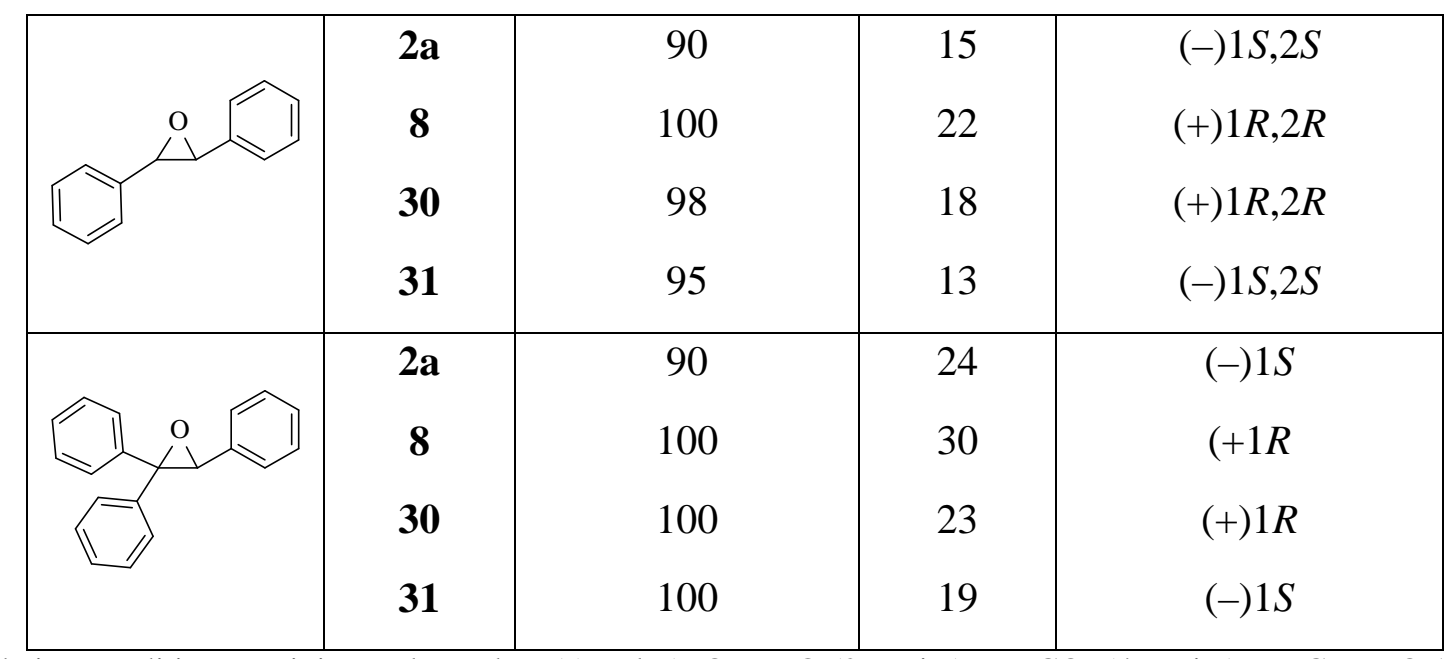

a Epoxidation conditions: Iminium salt catalyst (5 mol\%), Oxone ${ }^{\circledR}$ (2 equiv.). $\mathrm{Na}_{2} \mathrm{CO}_{3}$ (4 equiv.), $\mathrm{MeCN}: \mathrm{H}_{2} \mathrm{O}$ 1:1 (5 ml), $0{ }^{\circ} \mathrm{C}, 1-6 \mathrm{~h} .{ }^{\mathrm{b}}$ Enantiomeric excesses were determined by chiral GC chromatography on a Chiraldex B-DM column by comparison of the two epoxide peak areas. ${ }^{~}$ Conversions were evaluated from the chiral GC-FID spectra by comparison of the alkene and epoxide peak areas. ${ }^{d}$ Enantiomeric excess determined by Chiral HPLC on a Chiracel OD-H column. ${ }^{e}$ Conversions were evaluated from the ${ }^{1} \mathrm{H}$-NMR spectra by integration of alkene and epoxide signals. ${ }^{\mathrm{f}}$ Absolute configurations of the major enantiomers were determined by comparison of both optical rotation and GC-FID of samples of known configuration.

Catalysts 8, 30, and 31 provide greater enantioselectivity in the oxidation of 1-phenylcyclohexene than catalysts $\mathbf{2 8}$ and $\mathbf{2 9}$, and this pattern is repeated for the other alkene substrates tested. Observed enantioselectivities are comparable with or superior to the simple azepinium catalyst 3a. Highest enantioselectivities were observed with the cyclic cis-alkene dihydronaphthalene substrates, where catalysts $\mathbf{8}, \mathbf{3 0}$, and $\mathbf{3 1}$ outperformed catalyst $\mathbf{2 a}$ by a considerable margin.

\section{Conclusion}

To conclude, we have successfully developed a new sub-structure of iminium salt catalyst containing a 6,6,7,5-ring tetracyclic core. The synthesis of these novel iminium salts can be completed within four steps in good yields from the corresponding amino-alcohols. We have postulated that the cyclization occurs through one favoured atropoisomer, giving rise to a favoured diastereoisomer in all the iminium salt catalysts generated, that where the methyl group is pseudo-axial. Catalysts $\mathbf{8 ,} 30$ and $\mathbf{3 1}$ generally provide enantioselectivities better than or equal to the parent azepinium catalyst $\mathbf{2 a}$.

\section{Experimental Section}

\section{General Experimental Detail}

All infrared spectra were obtained using; thin films on sodium chloride plates. All ${ }^{1} \mathrm{H}$ and ${ }^{13} \mathrm{C}$ NMR spectra were measured at 400.13 and $100.62 \mathrm{MHz}$ respectively, or at 500.21 and $125.79 \mathrm{MHz}$ respectively, in deuteriochloroform solution unless otherwise stated, using TMS (tetramethylsilane) 
as the internal reference. Mass spectra were recorded utilizing electron-impact (EI), fast atom bombardment (FAB) or electrospray (ESI) techniques and an ion trap mass analyser. Optical rotation values were measured at $\lambda=589 \mathrm{~nm}$, corresponding to the sodium $\mathrm{D}$ line, at the temperatures indicated. All chromatographic manipulations used silica gel as the adsorbent. Reactions were monitored using thin layer chromatography (TLC) on aluminium-backed plates coated with F254 silica gel. TLC plates were visualized by UV irradiation at a wavelength of $254 \mathrm{~nm}$, or stained by exposure to an ethanolic solution of phosphomolybdic acid (acidified with concentrated sulfuric acid), followed by charring where appropriate. Reactions requiring anhydrous conditions were carried out using glassware dried overnight at $150{ }^{\circ} \mathrm{C}$, under a nitrogen atmosphere unless otherwise stated. Reaction solvents were used as obtained commercially unless otherwise stated. Light petroleum (b.p. $40-60{ }^{\circ} \mathrm{C}$ ) was distilled from calcium chloride prior to use. Ethyl acetate was distilled over calcium chloride. Dichloromethane was distilled over calcium hydride. Tetrahydrofuran and diethyl ether were distilled under a nitrogen atmosphere from the sodium/benzophenone ketyl radical. Acetone was dried over $4 \AA \AA$ Linde molecular sieve, and distilled under a nitrogen atmosphere. Enantiomeric excesses were determined by chiral HPLC using a Chiracel OD and OD-H columns with an ultra-violet absorption detector set at $254 \mathrm{~nm}$, by chiral GC using a Chiraldex B-DM column and a flame ionization detector, or by proton nuclear magnetic resonance spectroscopy in the presence of europium (III) tris[3(heptafluropropylhydroxymethylene)-(+)-camphorate] as the chiral shift reagent.

\section{General procedure A: Reductive amination using 2-iodobenzaldehyde and aminoalcohols}

The amino alcohol and 2-iodobenzaldehyde (1.1 equiv.) were dissolved in methanol $(10 \mathrm{~mL}$ per g of aminoalcohol) and agitated over 5 to $16 \mathrm{~h}$. The mixture was cooled to $0{ }^{\circ} \mathrm{C}$, sodium cyanoborohydride (1.1 equiv.) added, and the mixture stirred at ambient temperature for $16 \mathrm{~h}$. Saturated aqueous ammonium chloride ( $1 \mathrm{~mL}$ per $\mathrm{g}$ of aminoalcohol) was added and the solvent removed under reduced pressure. The residue was dissolved in tert-butyl methyl ether $(10 \mathrm{~mL}$ per $\mathrm{g}$ of aminoalcohol) and the solution washed with saturated brine and dried over magnesium sulphate. The solvents were removed and the crude oil purified by column chromatography using $\mathrm{CH}_{2} \mathrm{Cl}_{2} / \mathrm{MeOH}$ (100:0-95:5) as eluent to yield the desired secondary amine.

\section{General procedure B: Suzuki coupling between 2-iodobenzyl aminoalcohols and 2-acetyl phenylboronic acid}

The aminoalcohol and 2-acetyl phenylboronic acid (3 equiv.) were dissolved in toluene (10 mL per $\mathrm{g}$ of aminoalcohol) and ethanol (1 mL per $\mathrm{g}$ of aminoalcohol) and saturated aqueous potassium carbonate ( $1 \mathrm{~mL}$ per $\mathrm{g}$ of aminoalcohol) added. The mixture was degassed with nitrogen over 30 
min. $\mathrm{Pd}\left(\mathrm{PPh}_{3}\right)_{4}(10 \mathrm{~mol} \%)$ was added and the mixture degassed for a further $15 \mathrm{~min}$. The mixture was stirred at reflux under a nitrogen atmosphere with monitoring by HPLC; once complete consumption of the starting material was observed, the mixture was allowed to cool to ambient temperature and filtered through a plug of celite. The organic layer was separated, washed with water, dried over magnesium sulphate, and the solvents were removed under reduced pressure. The residue was dissolved in chloroform (10 mL per $\mathrm{g}$ of aminoalcohol and silica gel (0.5 $\mathrm{g}$ per $\mathrm{g}$ of aminoalcohol) added. The mixture was stirred for 15 hours at room temperature to achieve cyclization. The suspension was filtered through a plug of celite and the solvent removed under reduced pressure. The residue was purified using flash chromatography on silica gel using ethyl acetate:heptane (1-5\%) as eluent.

\section{General procedure C: Oxidation of tertiary cyclic amines using $N$-bromosuccinimide}

The amine was dissolved in chloroform ( $5 \mathrm{~mL}$ per $\mathrm{g}$ of amine) and the mixture cooled to $0{ }^{\circ} \mathrm{C}$. $\mathrm{N}$ Bromosuccinimide (2 equiv.) was added. The reaction mixture was removed from the ice bath and stirred for 15-20 min with monitoring by HPLC/TLC. Upon completion, water $(10 \mathrm{~mL}$ per g of amine) was added, and the organic layer separated and dried over magnesium sulphate. The solvent was removed under reduced pressure to yield the corresponding bromide salt. The residue was dissolved in ethanol (50 mL per g of bromide salt) and a solution of sodium tetraphenylborate (1 equiv.) in the minimum amount of acetonitrile to enable dissolution added. The solvents were removed under reduced pressure and the residue was recrystallized from ethanol to yield the desired tetracyclic imnium tetraphenylborate salts.

\section{General procedure for the formation of racemic epoxides for ee determinations}

The alkene was dissolved in dichloromethane $\left(10 \mathrm{~mL}\right.$ per $\mathrm{g}$ of alkene) and cooled to $0{ }^{\circ} \mathrm{C} . \mathrm{m}$-CPBA (2 equiv.) was added as a solution in dichloromethane (10 mL per $\mathrm{g}$ of alkene). The mixture was allowed to attain ambient temperature and stirred until complete consumption of the substrate was observed by TLC. Saturated aqueous $\mathrm{NaHCO}_{3}(20 \mathrm{~mL}$ per g of alkene) was added and the layers separated. The organic layer was washed with $\mathrm{NaOH}(1.0 \mathrm{M}, 20 \mathrm{~mL}$ per g of alkene), and dried $\left(\mathrm{MgSO}_{4}\right)$. The solvents were removed under reduced pressure and the product purified by column chromatography, eluting with ethyl acetate/light petroleum (1:99).

\section{General procedure for catalytic asymmetric epoxidation of simple alkenes mediated by iminium salts using Oxone}

Oxone (2 equiv.) was added to an ice cooled solution of $\mathrm{Na}_{2} \mathrm{CO}_{3}$, (4 equiv.) in water (8 $\mathrm{mL}$ per $\mathrm{g}$ of $\mathrm{Na}_{2} \mathrm{CO}_{3}$ ), and the resulting foaming solution stirred for 5-10 min. The iminium salt (10 mol\%) was 
added as a solution in acetonitrile ( $4 \mathrm{~mL}$ per $\mathrm{g}$ of $\mathrm{Na}_{2} \mathrm{CO}_{3}$ used), followed by the alkene substrate, also as a solution in acetonitrile ( $4 \mathrm{~mL}$ per $\mathrm{g}$ of $\mathrm{Na}_{2} \mathrm{CO}_{3}$ used). The mixture was stirred at $0{ }^{\circ} \mathrm{C}$ until the alkene substrate was completely consumed as observed by TLC. The mixture was dissolved in ice-cooled diethyl ether ( $20 \mathrm{~mL}$ per $100 \mathrm{mg}$ substrate), and the same volume of water added. The aqueous phase was washed four times with diethyl ether, and the combined organic layers were washed with saturated brine and dried over magnesium sulphate. Filtration and evaporation of the solvents gave a yellow/brown residue, which was purified by column chromatography, eluting with ethyl acetate/light petroleum (1:99).

\section{3-(2'-Iodobenzyl)-4R-phenyloxazolidin-2-one 14}

(R)-(-)-4-phenyl-2-oxazolidinone (0.20 g, $1.23 \mathrm{mmol}, 1.0$ equiv.) was dissolved in THF (2 mL) at room temperature under a nitrogen atmosphere. NaHMDS (2M in THF, $0.68 \mathrm{~mL}, 1.35 \mathrm{mmol}, 1.1$ equiv.) was added and the reaction mixture stirred for $30 \mathrm{~min}$. A solution of 2-iodobenzylbromide (0.40 g, 1.35 mmol, 1.1 equiv.) in THF ( $2 \mathrm{~mL}$ ) was added and the reaction monitored by HPLC. On complete consumption of the starting material, saturated aqueous potassium carbonate $(10 \mathrm{~mL}$ per $\mathrm{g}$ of oxazolidinone) and tert-butyl methyl ether (20 mL per g of oxazolidinone) were added. The organic layer was separated, washed with brine $(10 \mathrm{~mL}$ per g of oxazolidinone), dried over anhydrous magnesium sulphate, and the solvents removed under reduced pressure to yield the desired alkylated oxazolidinone (0.46 g, $1.21 \mathrm{mmol}$, 98\%); $v_{\max }\left(\right.$ film) $/ \mathrm{cm}^{-1}$ 2960, 1749, 1428, 1240, 1081, 1012, 751, 668. $[\alpha]^{20}{ }_{\mathrm{D}}-7.8^{\circ}\left(\mathrm{c} 1.0, \mathrm{CH}_{2} \mathrm{Cl}_{2}\right),{ }^{1} \mathrm{H}$ NMR $\left(400 \mathrm{MHz} ; \mathrm{CDCl}_{3}\right) \delta_{\mathrm{H}} 4.00(1 \mathrm{H}, \mathrm{d}, J$ 15.6 Hz), 4.17 (1 H, dd. J 5.6, $8.4 \mathrm{~Hz}), 4.56$ (1 H, dd, J 5.2, $9.2 \mathrm{~Hz}), 4.63$ (1 H, t, $J 8.3 \mathrm{~Hz}), 4.80$ (1 H, d, $J$ 15.4 Hz), 6.97 (1 H, td, J 1.5, 7.5 Hz), 7.14 - 7.20 (3 H, m), 7.29 (1 H, td, J 1.2, 7.5 Hz), 7.35 - 7.40 (3 H, m), 7.79 (1 H, dd, J 1.2, 7.9 Hz). $\left.{ }^{13} \mathrm{C} \mathrm{NMR} \mathrm{(100} \mathrm{MHz;} \mathrm{CHCl}_{3}\right) \delta_{\mathrm{C}}$ 50.7, 59.3, 70.1, 99.0, 127.2, 128.6, 129.2, 129.4, 129.7, 130.0, 137.8, 137.9, 140.0, 158.4; $\mathrm{m} / \mathrm{z}$ found for $[\mathrm{M}+\mathrm{H}]^{+}$ 380.0145; $\left[\mathrm{C}_{16} \mathrm{H}_{14} \mathrm{NO}_{2} \mathrm{I}+\mathrm{H}\right]^{+}$requires 380.0142.

\section{2-(2’-Iodobenzylamino)-2(R)-phenylethanol 17}

(R)-Phenylglycinol (1.32 g, 9.60 mmol, 1.1 equiv.) in $\mathrm{MeOH}$ (25 mL), 2-iodobenzaldehyde (2.20 g, 9.50 mmol, 1.0 equiv.) and $\mathrm{NaBH}_{3} \mathrm{CN}(0.60 \mathrm{~g}, 9.60 \mathrm{mmol}, 1.1$ equiv.) were treated using general procedure A to yield the desired product (2.77 g, $7.80 \mathrm{mmol}, 81 \%) ;[\alpha]^{20}{ }_{\mathrm{D}}-49.7^{\circ}\left(\mathrm{c} 1.0, \mathrm{CH}_{2} \mathrm{Cl}_{2}\right.$ ).

${ }^{1} \mathrm{H}$ NMR (400 MHz; $\left.\mathrm{CDCl}_{3}\right) \delta_{\mathrm{H}} 3.58(1 \mathrm{H}, \mathrm{dd}, J$ 8.6, $10.8 \mathrm{~Hz}), 3.66(1 \mathrm{H}, \mathrm{d}, J 13.2 \mathrm{~Hz}), 3.73(1 \mathrm{H}$, dd, $J$ 4.4, 10.8 Hz), 3.78 (1 H, d, $J 13.2$ Hz), 3.81 (1 H, dd, J 4.4, 8.4 Hz), 6.93-6.98 (1 H, m), 7.267.40 (7 H, m), 7.80-7.83 (1 H, m); ${ }^{13} \mathrm{C}$ NMR (100 MHz; $\left.\mathrm{CHCl}_{3}\right) \delta_{\mathrm{C}}$ 55.8, 64.0, 67.0, 100.0, 127.5, 127.9, 128.4, 128.8, 129.1, 130.2, 139.8, 140.3, 142.2; $\mathrm{m} / \mathrm{z}$ found for $[\mathrm{M}+\mathrm{H}]^{+}: 354.0363$; 
$\left[\mathrm{C}_{15} \mathrm{H}_{16} \mathrm{INO}+\mathrm{H}\right]^{+}$requires 354.0355.

\section{3-(2'-Iodobenzyl)-2,2-dimethyl-(4R)-phenyloxazolidine 18}

(2R)-2-(2'-Iodo-benzylamino)-2-phenyl-ethanol 17 (650 mg, $1.84 \mathrm{mmol}, 1$ equiv.) was dissolved in toluene (10 mL). Dimethoxypropane (2.25 mL, $18.40 \mathrm{mmol}, 10$ equiv.) and p-TSA (70.0 mg, 0.37 mmol, 0.2 equiv.) were added, and the mixture heated under reflux using a Dean-Stark apparatus. The reaction was monitored by TLC and the azeotropic removal of solvents. Upon completion, the mixture was allowed to reach ambient temperature. Saturated brine ( 3 x $20 \mathrm{~mL}$ ) was added and the organic phase separated, dried over $\mathrm{MgSO}_{4}$, and the solvents removed under reduced pressure. Purification using column chromatography on silica gel (washed with 4\% TEA) using ethylacetate/light petroleum (10\%) as eluent yielded the desired acetal as a yellow low-melting solid (694 mg, 1.76 mmol, 96\%); $v_{\max }\left(\right.$ film) /cm ${ }^{-1}$ 3420, 2972, 1455, 1362, 1255, 1187, 1054, 1011, 753, 700; $[\alpha]^{20}{ }_{\mathrm{D}}-60.2$ (c 1.19, $\left.\mathrm{CHCl}_{3}\right) ;{ }^{1} \mathrm{H}$ NMR (400 MHz; $\left.\mathrm{CDCl}_{3}\right) \delta_{\mathrm{H}} 1.34$ (3 H, s), 1.37 (3 H, s), 3.67 (1 H,d, J 14.4 Hz), 3.75 (1 H, t, J 8.0 Hz), 3.88 (1 H, d, J 14.8 Hz), 4.08 (1 H, t, J 7.6 Hz), 4.21 (1 H, t, J 7.2 Hz), 6.75 (1 H, dt, J 1.6, 7.6 Hz), 7.09-7.14 (2 H, m), 7.15-7.20 (2 H, m), 7.32-7.36 (2 H, m), $7.43(1 \mathrm{H}, \mathrm{dd}, J$ 1.6, $7.6 \mathrm{~Hz}), 7.61(1 \mathrm{H}, \mathrm{dd}, J$ 1.2, $8.0 \mathrm{~Hz}) ;{ }^{13} \mathrm{C} \mathrm{NMR}\left(100 \mathrm{MHz} ; \mathrm{CHCl}_{3}\right) \delta_{\mathrm{C}} 21.6$, 28.7, 56.8, 67.8, 72.1, 96.4, 99.6, 127.5, 127.7, 128.1, 128.2, 128.5, 131.3, 139.1, 140.5, 141.2; $\mathrm{m} / \mathrm{z}$ found for $\mathrm{M}^{+}$: 393.0583; $\left[\mathrm{C}_{18} \mathrm{H}_{20} \mathrm{INO}\right]^{+}$requires 393.0590.

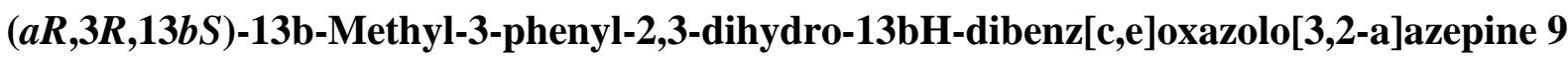

\section{First method: from oxazolidinone 14}

(4R)-3-(2'-Iodo-benzyl)-4-phenyl-oxazolidin-2-one 14 (0.46 g, $1.21 \mathrm{mmol}$ ) was dissolved in toluene (5 mL) and ethanol (7.5 mL). 2-Acetyl phenylboronic acid (0.20 g, $1.21 \mathrm{mmol}, 1$ equiv.) and saturated aqueous potassium carbonate $(5 \mathrm{~mL})$ were added. The mixture was degassed with nitrogen over $30 \mathrm{~min}$. $\mathrm{Pd}\left(\mathrm{PPh}_{3}\right)_{4}(0.07 \mathrm{~g}, 0.06 \mathrm{mmol}, 5 \mathrm{~mol} \%)$ was added, and the mixture was degassed with nitrogen for a further $15 \mathrm{~min}$. The mixture was stirred under reflux under a nitrogen atmosphere with monitoring by HPLC. Once complete consumption of the starting material was observed, the mixture was allowed to cool to ambient temperature. The mixture was filtered through a plug of celite, and the solvents were removed under reduced pressure. tert-Butyl methyl ether $(10 \mathrm{~mL})$ and water (5 $\mathrm{mL}$ ) were added to the residue. The organic layer was separated, washed with water $(5 \mathrm{~mL})$, and dried over $\mathrm{MgSO}_{4}$. The solvents were removed under reduced pressure, and the residue dissolved in ethanol $(5 \mathrm{~mL})$ and aqueous $\mathrm{NaOH}(2 \mathrm{M}, 5 \mathrm{~mL})$ added. The mixture was heated under reflux for $16 \mathrm{~h}$ to remove the protecting goup, then allowed to cool to ambient temperature. The organic solvent was removed under reduced pressure, the residue was dissolved in tert-butyl methyl ether (5 mL), and aqueous $\mathrm{HCl}(5 \mathrm{M}, 1 \mathrm{~mL})$ added. The mixture was stirred for $30 \mathrm{~min}$ to achieve cyclization, and the 
organic layer separated, dried over magnesium sulphate and the solvents removed under reduced pressure. The residue was purified using flash chromatography on silica gel using ethyl acetate:heptane $(1-5 \%)$ as eluent to give the desired product $(0.049 \mathrm{~g}, 0.15 \mathrm{mmol}, 12 \%)$.

\section{Second method: from oxazolidine 18}

(4R)-3-(2-Iodo-benzyl)-2,2-dimethyl-4-phenyl-oxazolidine 18 (0.69 g, $1.76 \mathrm{mmol}$ ) was dissolved in toluene (10 mL) and ethanol (15 mL). 2-Acetyl phenylboronic acid (0.29 g, $1.76 \mathrm{mmol}, 1$ equiv.) and saturated aqueous potassium carbonate $(10 \mathrm{~mL})$ were added. The mixture was degassed with nitrogen over $30 \mathrm{~min} . \mathrm{Pd}\left(\mathrm{PPh}_{3}\right)_{4}(0.10 \mathrm{~g}, 0.09 \mathrm{mmol}, 5 \mathrm{~mol} \%)$ was added, and the mixture degassed with nitrogen for a further $15 \mathrm{~min}$. The mixture was stirred under reflux under a nitrogen atmosphere for $4 \mathrm{~h}$. The mixture was allowed to cool to ambient temperature, filtered through a plug of celite, and the solvents were removed under reduced pressure. tert-Butyl methyl ether (10 mL) and water (5 $\mathrm{mL}$ ) were added to the residue. The organic layer was separated, washed with water (5 $\mathrm{mL})$ and dried over $\mathrm{MgSO}_{4}$. The solvents were removed under reduced pressure, and the residue dissolved in chloroform $(10 \mathrm{~mL})$ and silica gel added. The mixture was stirred at room temperature for $30 \mathrm{~min}$ and the suspension filtered through a pad of celite. The solvent was removed under reduced pressure and the residue purified using flash chromatography on silica gel using ethyl acetate:heptane (1-5\%) as eluent to give the desired product ( $0.23 \mathrm{~g}, 0.70 \mathrm{mmol}, 40 \%)$.

\section{Third method: from amino alcohol 17}

(2R)-(2'-Iodobenzylamino)-2-phenylethanol 17 (2.29 g, $6.50 \mathrm{mmol}$ ) and 2-acetyl phenylboronic acid (3.20 g, 19.5 mmol, 3 equiv.) were treated using general procedure $B$ to yield the desired product (0.85 g, $2.60 \mathrm{mmol}, 40 \%) ; v_{\max }(\mathrm{film}) / \mathrm{cm}^{-1}$ 2963, 1449, 1260, 1153, 1038, 897, 802, 758, 740, 701. $[\alpha]^{20}{ }_{\mathrm{D}}-15.6^{\circ}\left(c\right.$ 1.0, $\left.\mathrm{CH}_{2} \mathrm{Cl}_{2}\right) .{ }^{1} \mathrm{H}$ NMR (400 MHz; $\left.\mathrm{CDCl}_{3}\right) \delta_{\mathrm{H}} 1.11(3 \mathrm{H}, \mathrm{s}), 3.09(1 \mathrm{H}, \mathrm{d}, J$ $10.8 \mathrm{~Hz}$ ), 3.58 (1 H, d, $J 10.8 \mathrm{~Hz}$ ), 3.86 (1 H, dd, J 7.6, $9.2 \mathrm{~Hz}$ ), 3.94 (1 H, dd, J 6.0, 9.6 Hz), 4.37 (1 H, t, J 6.8 Hz), 7.25 (1 H, d, J 6.8 Hz), 7.30-7.37 (2 H, m), 7.38-7.45 (3 H, m), 7.46-7.53 (6 H, m), 7.86-7.92 (1 H, m); ${ }^{13} \mathrm{C}$ NMR $\left(100 \mathrm{MHz} ; \mathrm{CHCl}_{3}\right) \delta_{\mathrm{C}} 30.6,52.5,69.3,72.8,97.3,125.8,127.6,127.8$, 127.9, 128.00, 128.04, 128.1, 128.5, 128.8, 129.1, 128.2, 135.3, 137.0, 139.1, 140.4, 142.1; m/z found for $\mathrm{M}^{+}$327.1626; $\left[\mathrm{C}_{23} \mathrm{H}_{21} \mathrm{NO}\right]^{+}$requires 327.1623.

\section{S-(2'-Iodobenzylamino)-propan-1-ol 20}

(S)-Alaninol (1.3 mL, $16.38 \mathrm{mmol}$ ) and 2-iodobenzaldehyde (3.8 g, $16.38 \mathrm{mmol}, 1$ equiv.) were dissolved in toluene $(100 \mathrm{~mL})$ in a round-bottomed flask fitted with a Dean-Stark apparatus. Acetic acid $(0.5 \mathrm{~mL})$ was added and the solution heated under reflux for $16 \mathrm{~h}$. The reaction mixture was allowed to reach room temperature and the solvents were removed under reduced pressure. The 
residue was dissolved in methanol (50 mL), $\mathrm{NaBH}_{3} \mathrm{CN}$ (1.23 g, $19.66 \mathrm{mmol}, 1.2$ equiv.) and acetic acid $(1 \mathrm{~mL})$ were added, and the solution was stirred for $16 \mathrm{~h}$. Saturated aqueous $\mathrm{NH}_{4} \mathrm{Cl}(20 \mathrm{~mL})$ was added, and the aqueous layer washed with $\mathrm{Et}_{2} \mathrm{O}(3 \times 20 \mathrm{~mL})$. The combined organic layers were washed with a saturated solution of aqueous $\mathrm{NH}_{4} \mathrm{Cl}(20 \mathrm{~mL})$. The aqueous layers were combined and the $\mathrm{pH}$ of the solution was brought to 8-9 using a saturated solution of $\mathrm{Na}_{2} \mathrm{CO}_{3}$. The resulting solution was extracted using dichloromethane (3 x $20 \mathrm{~mL})$ and the combined organic layers were washed with water and brine, dried over $\mathrm{MgSO}_{4}$, filtered, and the solvents removed to yield the product (4.0 g, 13.75 mmol, 83\%); $v_{\max }\left(\right.$ film) /cm ${ }^{-1}$ 3324, 2956, 1563, 1435, 1045, 1011, 750, 648. $[\alpha]^{20}{ }_{\mathrm{D}}+10.8^{\circ}\left(\mathrm{c} 1.0, \mathrm{CH}_{2} \mathrm{Cl}_{2}\right) .{ }^{1} \mathrm{H}$ NMR $\left(500 \mathrm{MHz} ; \mathrm{CDCl}_{3}\right) \delta_{\mathrm{H}} 1.08(3 \mathrm{H}, \mathrm{d}, J 6.0 \mathrm{~Hz}), 2.78-2.85$ (1 H, m), 3.29 (1 H, dd, J 7.0, 11.0 Hz), 3.58 (1 H, dd, J 4.0, 11.0 Hz), 3.74 (1 H, d, J 13.5 Hz), 3.87 (1 H, d, $J 13.5 \mathrm{~Hz}$ ), 6.94 (1 H, dt, J 1.5, $7.5 \mathrm{~Hz}) 7.30$ (1 H, dt, $J$ 1.0, 7.5 Hz), 7.35 (1 H, dd, $J$ 1.5, 7.5 $\mathrm{Hz}), 7.81(1 \mathrm{H}$, dd, $J$ 1.2, $8.0 \mathrm{~Hz}) .{ }^{13} \mathrm{C} \mathrm{NMR}\left(125 \mathrm{MHz} ; \mathrm{CHCl}_{3}\right) \delta_{\mathrm{C}} 17.1,53.9,55.6,65.6,99.8$, 128.4, 129.0, 129.8, 139.6, 142.2; $\mathrm{m} / \mathrm{z}$ found for $[\mathrm{M}+\mathrm{H}]^{+}:$292.0204; $\left[\mathrm{C}_{10} \mathrm{H}_{14} \mathrm{NOI}+\mathrm{H}\right]^{+}$requires 292.0198 .

\section{S-(2'-Iodobenzylamino)-3-methyl-butan-1-ol 21}

(S)-Valinol (2.56 g, $24.8 \mathrm{mmol})$ in $\mathrm{MeOH}$ (50 mL), 2-iodobenzaldehyde (6.33 g, $27.3 \mathrm{mmol}, 1.1$ equiv.) and $\mathrm{NaBH}_{3} \mathrm{CN}$ (1.71 g, $27.3 \mathrm{mmol}, 1.1$ equiv.) were treated using general procedure $\mathrm{A}$ to yield the product (1.30 g, $4.09 \mathrm{mmol}, 16 \%) ; v_{\max }(\mathrm{film}) / \mathrm{cm}^{-1} 3321,2956,1563,1464,1435,1045$, 1011, 750, 648. $[\alpha]^{20}{ }_{\mathrm{D}}-16.7^{\circ}\left(\mathrm{c} 1.5, \mathrm{CHCl}_{3}\right) .{ }^{1} \mathrm{H}$ NMR $\left(400 \mathrm{MHz} ; \mathrm{CDCl}_{3}\right) \delta_{\mathrm{H}} 0.93(3 \mathrm{H}, \mathrm{d}, J 6.8$ Hz), 0.99 (3 H, d, $J 6.8 \mathrm{~Hz}), 1.81(1 \mathrm{H}$, sextet, $J 6.8 \mathrm{~Hz}), 2.41(1 \mathrm{H}, \mathrm{dt}, J$ 4.0, $6.4 \mathrm{~Hz}), 3.40$ (1 H, dd $J$ 6.8, $10.8 \mathrm{~Hz}), 3.68$ (1 H, dd, J 4.0, $10.8 \mathrm{~Hz}), 3.78$ (1 H, d, $J 13.2 \mathrm{~Hz}), 3.88$ (1 H, d, $J 13.2 \mathrm{~Hz}), 6.97$ (1 H, dt, $J$ 2.0, 7.6 Hz), 7.32 (1 H, dt, $J$ 1.2, 7.2 Hz), 7.36 (1 H, dd, $J$ 1.6, 7.6 Hz), 7.83 (1 H, dd, $J$ 0.8, 8.0 Hz); ${ }^{13} \mathrm{C}$ NMR (100 MHz; $\left.\mathrm{CHCl}_{3}\right) \delta_{\mathrm{C}} 18.7,19.8,29.1,56.0,60.6,64.1,100.0,128.6,129.2$, 130.1, 139.7, 142.5; $\mathrm{m} / \mathrm{z}$ found for $[\mathrm{M}+\mathrm{H}]^{+} 320.0511 ;\left[\mathrm{C}_{12} \mathrm{H}_{18} \mathrm{INO}+\mathrm{H}\right]^{+}$requires 320.0511 .

\section{R-(2'-Iodobenzylamino)-3-phenyl-propan-1-ol 22}

(2R)-2-Amino-3-phenylpropan-1-ol (2.92 g, $19.6 \mathrm{mmol}$ ) in $\mathrm{MeOH}$ (50 mL), 2-iodobenzaldehyde (3.00 g, 21.5 mmol, 1.1 equiv.) and $\mathrm{NaBH}_{3} \mathrm{CN}$ (1.35 g, $21.5 \mathrm{mmol}, 1.1$ equiv.) were treated using general procedure A to yield the product $(6.47 \mathrm{~g}, 17.6 \mathrm{mmol}, 90 \%) ; v_{\max }($ film $) / \mathrm{cm}^{-1} 3441,2359$, 1652, 1635, 1113, 743, 699, 668. $[\alpha]^{20}{ }_{\mathrm{D}}+20.0^{\circ}$ (c 1.5, $\left.\mathrm{CHCl}_{3}\right) .{ }^{1} \mathrm{H}$ NMR $\left(400 \mathrm{MHz} ; \mathrm{CDCl}_{3}\right) \delta_{\mathrm{H}} 2.81$ (2 H, qd, J 7.2, 14.0 Hz), 2.93-3.00 (1 H, m), 3.38 (1 H, dd, J 5.2, 10.8 Hz), 3.71 (1 H, dd, J 4.0, 10.8 Hz), 3.80 (2 H, s), 6.95 (1 H, dt, J 1.6, 7.6 Hz), 7.14-7.18 (2 H, m), 7.19-7.24 (2 H, m), 7.25-7.31 (3 H, m), 7.79 (1 H, dd, J 1.2, 8.0 Hz); ${ }^{13} \mathrm{C}$ NMR (100 MHz; $\left.\mathrm{CHCl}_{3}\right) \delta_{\mathrm{C}} 38.4,55.7,59.5,62.6,100.0$, 
126.7, 128.5, 128.8, 129.2, 129.4, 129.9, 138.4, 139.7, 142.0; $\mathrm{m} / \mathrm{z}$ found for $[\mathrm{M}+\mathrm{H}]^{+} 368.0506$; $\left[\mathrm{C}_{16} \mathrm{H}_{18} \mathrm{NOI}+\mathrm{H}\right]^{+}$requires 368.0510 .

\section{S-(2'-Iodobenzylamino)-3-phenyl-propan-1-ol 23}

(2S)-2-Amino-3-phenylpropan-1-ol (2.92 g, $19.6 \mathrm{mmol}$ ) in $\mathrm{MeOH}$ (50 mL), 2-iodobenzaldehyde (3.00 g, 21.5 mmol, 1.1 equiv.) and $\mathrm{NaBH}_{3} \mathrm{CN}$ (1.35 g, $21.5 \mathrm{mmol}, 1.1$ equiv.) were treated using general procedure A to yield the product $(6.19 \mathrm{~g}, 16.9 \mathrm{mmol}, 86 \%) ; v_{\max }($ film $) / \mathrm{cm}^{-1} 3450,2358$, 1645, 1112, 745, 670, 668. $[\alpha]^{20}{ }_{\mathrm{D}}-22.8^{\circ}\left(c\right.$ 1.3, $\left.\mathrm{CHCl}_{3}\right) .{ }^{1} \mathrm{H}$ NMR $\left(400 \mathrm{MHz} ; \mathrm{CDCl}_{3}\right) \delta_{\mathrm{H}} 2.81(2 \mathrm{H}$, qd, $J$ 7.2, 14.0 Hz), 2.93-3.00 (1 H, m), 3.38 (1 H, dd, $J$ 5.2, $10.8 \mathrm{~Hz}), 3.70(1 \mathrm{H}, \mathrm{dd}, J$ 3.6, $10.8 \mathrm{~Hz})$, 3.80 (2 H, s), 6.95 (1 H, dt, J 2.0, 8.0 Hz), 7.14-7.18 (2 H, m), 7.19-7.24 (2 H, m), 7.26-7.31 (3 H, m), 7.79 (1 H, dd, $J$ 1.2, $8.0 \mathrm{~Hz}$ ); ${ }^{13} \mathrm{C} \mathrm{NMR}\left(100 \mathrm{MHz} ; \mathrm{CHCl}_{3}\right) \delta_{\mathrm{C}}$ 38.4, 55.7, 59.5, 62.7, 100.0, 126.7, 128.5, 128.8, 129.1, 129.4, 129.9, 138.4, 139.7, 142.0; $\mathrm{m} / \mathrm{z}$ found for $[\mathrm{M}+\mathrm{H}]^{+} 368.0506$; $\left[\mathrm{C}_{16} \mathrm{H}_{18} \mathrm{INO}+\mathrm{H}\right]^{+}$requires 368.0510 .

\section{(aS,3S,13bR)-3,13b-Dimethyl-2,3-dihydro-13bH-dibenz[c,e]oxazolo[3,2-a]azepine 24}

(2S)-2-(2'-Iodo-benzylamino)-propan-1-ol 20 (1.05 g, $3.60 \mathrm{mmol}$ ) and 2-acetyl phenylboronic acid (1.77 g, $10.8 \mathrm{mmol}, 3$ equiv.) were treated using general procedure B to yield the product ( $0.21 \mathrm{~g}$, 0.80 mmol, 22\%); $v_{\max }\left(\right.$ film) $/ \mathrm{cm}^{-1} 3377,2966,1448,1365,1217,1161,1097,1046,756,738 .[\alpha]^{20}$ $-69.2^{\circ}$ (c 0.96, $\left.\mathrm{CHCl}_{3}\right) ;{ }^{1} \mathrm{H}$ NMR (400 MHz; $\left.\mathrm{CDCl}_{3}\right) \delta_{\mathrm{H}} 0.98(3 \mathrm{H}, \mathrm{s}), 1.22$ (3 H, d, J 6.0 Hz), 2.852.94 (1 H, m), 3.01 (1 H, d, J 10.8 Hz), 3.68 (1 H, dd, J 7.6, 9.6 Hz), 3.86 (1 H, d, J 11.2 Hz), 4.20 (1 H, dd, $J$ 6.4, 7.6 Hz), 7.32-7.46 (7 H, m), 7.74-7.79 (1 H, m); ${ }^{13} \mathrm{C}$ NMR (100 MHz; $\left.\mathrm{CHCl}_{3}\right) \delta_{\mathrm{C}} 15.9$, 30.5, 52.9, 59.7, 71.7, 97.5, 121.8, 125.9, 127.6, 127.7, 128.1, 128.7, 129.0, 129.3, 134.9, 136.9, 142.4; $\mathrm{m} / \mathrm{z}$ found for $[\mathrm{M}+\mathrm{H}]^{+}$266.1542; $\left[\mathrm{C}_{18} \mathrm{H}_{19} \mathrm{NO}+\mathrm{H}\right]^{+}$requires 266.1539.

\section{(aS,3S,13bR)-13b-Methyl-3-isopropyl-2,3-dihydro-13bH-dibenz[c,e]oxazolo[3,2-a]azepine 25}

(2S)-2-(2'-Iodobenzylamino)-3-methyl-butan-1-ol $21 \quad(1.30 \quad$ g, 4.09 mmol) and 2-acetyl phenylboronic acid (2.01 g, $12.3 \mathrm{mmol}, 3$ equiv.) were treated using general procedure $\mathrm{B}$ to yield the product (0.54 g, $1.90 \mathrm{mmol}, 47 \%)$; $v_{\max }\left(\right.$ film) $/ \mathrm{cm}^{-1}$ 3419, 2954, 2871, 1459, 1365, 1213, 1160, 1043, 756, 730. $[\alpha]^{20}{ }_{\mathrm{D}}-98.8^{\circ}\left(\mathrm{c} 1.21, \mathrm{CHCl}_{3}\right) .{ }^{1} \mathrm{H} \mathrm{NMR}\left(400 \mathrm{MHz} ; \mathrm{CDCl}_{3}\right) \delta_{\mathrm{H}} 0.96(3 \mathrm{H}, \mathrm{s}), 0.99(6 \mathrm{H}, \mathrm{d}$, $J 6.8 \mathrm{~Hz}), 1.88$ (1 H, octet, $J 6.8 \mathrm{~Hz}), 2.82$ (1 H, q, $J 6.0 \mathrm{~Hz}), 3.24$ (1 H, d, $J 11.2 \mathrm{~Hz}), 3.74$ (1 H, d, $J$ $11.2 \mathrm{~Hz}$ ), 3.86 (1 H, dd, J 6.0, 8.0 Hz), 4.02 (1 H, dd, J 7.0, 8.0 Hz), 7.34-7.37 (2 H, m), 7.38-7.43 (3 $\mathrm{H}, \mathrm{m}), 7.44-7.48$ (2 H, m), 7.69-7.74 (1 H, m); ${ }^{13} \mathrm{C}$ NMR (100 MHz; $\left.\mathrm{CHCl}_{3}\right) \delta_{\mathrm{C}} 17.1,19.6,30.2$, 30.5, 54.3, 65.8, 70.1, 98.2, 125.2, 127.6, 127.90, 127.91, 128.0, 128.3, 129.1, 135.8, 137.4, 140.5, 142.1; $\mathrm{m} / \mathrm{z}$ found for $[\mathrm{M}+\mathrm{H}]^{+}: 294.1857\left[\mathrm{C}_{20} \mathrm{H}_{23} \mathrm{NO}+\mathrm{H}\right]^{+}$requires 294.1852. 
(aR,3R,13bS)-13b-Methyl-3-benzyl-2,3-dihydro-13bH-dibenz[c,e]oxazolo[3,2-a]azepine 26

(2R)-2-(2'-Iodobenzylamino)-3-phenyl-propan-1-ol 22 (1.00 g, $2.70 \mathrm{mmol})$ and 2-acetyl phenylboronic acid (1.34 g, $8.20 \mathrm{mmol}, 3$ equiv.) were treated using general procedure $\mathrm{B}$ to yield the product (0.51 g, $1.60 \mathrm{mmol}, 60 \%)$; ( $v_{\max }\left(\right.$ film) $/ \mathrm{cm}^{-1}$ 2926, 1493, 1452, 1365, 1215, 1158, 1069, 1043, 761, 738, 700. $[\alpha]^{20}{ }_{\mathrm{D}}-130.1^{\circ}\left(\mathrm{c} 0.99, \mathrm{CHCl}_{3}\right) ;{ }^{1} \mathrm{H}$ NMR (500 MHz; $\left.\mathrm{CDCl}_{3}\right) \delta_{\mathrm{H}} 0.93(3 \mathrm{H}, \mathrm{s})$, 2.60-2.67 (1 H, m), 2.99-3.06 (2 H, m), 3.09 (1 H, d, $J 11 \mathrm{~Hz}), 3.66$ (1 H, d, J $11 \mathrm{~Hz}), 3.75$ (1 H, t, $J$ 7.5 Hz), 3.93 (1 H, dd, J 6.5, 8.0 Hz). 7.11-7.16 (3 H, m), 7.18-7.24 (3 H, m), 7.24-7.27 (1 H, m), 7.27- 7.32 (2 H, m), 7.32-7.39 (3 H, m), 7.63 (1 H, dd, $J$ 1.5, $7.5 \mathrm{~Hz}) ;{ }^{13} \mathrm{C}$ NMR $\left(125 \mathrm{MHz} ; \mathrm{CHCl}_{3}\right)$ $\delta_{\mathrm{C}} 30.6,39.7,53.5,66.2,69.9,98.1,125.4,126.4,127.5,127.8,128.0,128.5,129.0,129.1,129.2$, 135.0, 137.1, 138.8, 140.1, 142.0; $\mathrm{m} / \mathrm{z}$ found for $[\mathrm{M}+\mathrm{H}]^{+}: 342.1853 ;\left[\mathrm{C}_{24} \mathrm{H}_{23} \mathrm{NO}+\mathrm{H}\right]^{+}$requires 342.1858 .

\section{(aS,3S,13bR)-13b-Methyl-3-benzyl-2,3-dihydro-13bH-dibenz[c,e]oxazolo[3,2-a]azepine 27}

(2S)-2-(2'-Iodobenzylamino)-3-phenylpropan-1-ol $23 \quad(1.00 \quad$ g, 2.70 mmol) and 2-acetyl phenylboronic acid (1.34 g, $8.20 \mathrm{mmol}, 3$ equiv.) were treated using general procedure $\mathrm{B}$ to yield the product (0.27 g, $0.80 \mathrm{mmol}, 30 \%)$; $v_{\max }\left(\right.$ film) $/ \mathrm{cm}^{-1}$ 2926, 1493, 1452, 1365, 1215, 1158, 1069, 1043, 761, 738, 700. $[\alpha]^{20}{ }_{\mathrm{D}}+130.9^{\circ}\left(\mathrm{c} 1.10, \mathrm{CHCl}_{3}\right) .{ }^{1} \mathrm{H}$ NMR $\left(400 \mathrm{MHz} ; \mathrm{CDCl}_{3}\right) \delta_{\mathrm{H}} 1.01$ (3 H, s), 2.682.76 (1 H, m), 3.07-3.19 (3 H, m), 3.75 (1 H, d, J $10.8 \mathrm{~Hz}), 3.83$ (1 H, t, $J$ 7.6 Hz), 4.02 (1 H, dd, $J$ 6.2, 7.6 Hz), 7.20-7.26 (3 H, m), 7.27-7.33 (3 H, m), 7.34-7.41 (3 H, m), 7.42-7.48 (3 H, m), 7.68$7.72(1 \mathrm{H}, \mathrm{m}) ;{ }^{13} \mathrm{C}$ NMR $\left(100 \mathrm{MHz} ; \mathrm{CHCl}_{3}\right) \delta_{\mathrm{C}} 30.7,39.7,53.6,66.3,70.0,98.2,125.5,126.5$, 127.6, 127.9, 128.0, 128.6, 129.1, 129.2, 129.3, 135.0, 137.1, 138.9, 140.1, 142.1; m/z [M+H] $]^{+}$ 342.1853; $\left[\mathrm{C}_{24} \mathrm{H}_{23} \mathrm{NO}+\mathrm{H}\right]^{+}$requires 342.1858.

\section{(aS,3S,13bR)-3,13b-Dimethyl-2,3-dihydro-13bH-dibenz[c,e]oxazolo[3,2-a]azepin-5-ium tetraphenylborate salt 28}

Compound $24(0.21 \mathrm{~g}, 0.80 \mathrm{mmol})$ in dichloromethane $(2 \mathrm{~mL})$ and $N$-bromosuccinimide $(0.29 \mathrm{~g}$, $1.60 \mathrm{mmol}, 2$ equiv.) were treated using general procedure $\mathrm{C}$ to yield the product $(0.20 \mathrm{~g}, 0.59 \mathrm{mmol}$, 74\%); $v_{\max }\left(\right.$ film) $/ \mathrm{cm}^{-1} 2965,1704,1652,1558,1259,1184,1102,1017,763,615 .[\alpha]^{20}{ }_{D} 107.6^{\circ}(c$ 10.3, $\mathrm{CHCl}_{3}$ ); ${ }^{1} \mathrm{H}$ NMR (500 MHz; d6-acetone) $\delta_{\mathrm{H}} 1.56(3 \mathrm{H}, \mathrm{s}), 1.90$ (3 H, d, J 6.8 Hz), $4.48(1 \mathrm{H}$, dd, $J$ 2.9, $9.5 \mathrm{~Hz}), 4.54$ (1 H, dd, $J 5.3$ \& 9.5 Hz), 4.96-5.03 (1 H, m), 6.74-6.78 (4 H, m), 6.91 (8 H, t, J 7.4 Hz), 7.31-7.35 (8 H, m), $7.71(1 \mathrm{H}, \mathrm{dt}, J$ 1.5, $7.5 \mathrm{~Hz}), 7.76$ (1 H, dt, J 1.4, 7.5 Hz), 7.84-7.89 (2 H, m), 7.91 (1 H, dd, J 1.1, $7.6 \mathrm{~Hz}), 8.10$ (1 H, dt, J 1.2, 7.4 Hz), 8.16-8.20 (2 H, m), 9.67 (1 H, s); ${ }^{13} \mathrm{C}$ NMR (125 MHz; d6-acetone) $\delta_{\mathrm{C}}$ 19.7, 23.4, 65.8, 71.5, 100.4, 122.3, 124.6, 126.0 (q, $3 \mathrm{~Hz}$ ), 
129.9, 131.4, 131.5, 131.7, 132.6, 134.6, 136.0, 137.0, 137.9, 139.3, 143.1, 164.4, 164.8, 165.1, 165.5, 165.7; m/z found for iminium cation: 264.1385; $\mathrm{C}_{18} \mathrm{H}_{18} \mathrm{NO}^{+}$requires 264.1383.

\section{(aS,3S,13bR)-13b-Methyl-3-isopropyl-2,3-dihydro-13bH-dibenz[c,e]oxazolo[3,2-a]azepin-5-ium} tetraphenylborate salt 29

Compound 25 (0.54 g, $1.90 \mathrm{mmol})$ in dichloromethane $(2 \mathrm{~mL})$ and $N$-bromosuccinimide (0.68 g, $3.80 \mathrm{mmol}$, 2 equiv.) were treated using general procedure $\mathrm{C}$ to yield the product $(0.57 \mathrm{~g}, 1.50 \mathrm{mmol}$, 81\%); $v_{\max }\left(\right.$ film) /cm ${ }^{-1}$ 3055, 2998, 1639, 1596, 1579, 1559, 1479, 1425, 1377, 1184, 1031, 734. $[\alpha]^{20}{ }_{\mathrm{D}}+236.8^{\circ}\left(c\right.$ 2.0, $\left.\mathrm{CHCl}_{3}\right) ;{ }^{1} \mathrm{H}$ NMR $\left(500 \mathrm{MHz}\right.$; d6-acetone) $\delta_{\mathrm{H}} 1.24(3 \mathrm{H}, \mathrm{d}, J 7.0 \mathrm{~Hz}), 1.26(3$ H, d, J 7.0 Hz), 1.54 (3 H, s), 2.64 (1 H, sextet, J 7.0 Hz), 4.47 (1 H, dd, J 5.0, 10.0 Hz), 4.60 (1 H, tt, $J$ 1.5, $6.5 \mathrm{~Hz}), 4.72$ (1 H, dd, $J$ 2.0, $10.0 \mathrm{~Hz}), 6.79$ (4 H, t, $J 7.2 \mathrm{~Hz}), 6.93$ (8 H, t, $J 7.5 \mathrm{~Hz}), 7.33-$ 7.37 (8 H, m), 7.73 (1 H, td, $J$ 1.5, $7.5 \mathrm{~Hz}), 7.77$ (1 H, td, $J$ 1.5, 7.5 Hz), 7.83-7.87 (2 H, m), 7.92 (1 H, dd, J 1.5, 7.5 Hz), 8.09 (1 H, td, J 1.5, 7.5 Hz), 8.14 (1 H, dd, J 1.5, 7.5 Hz), 8.18 (1 H, d, 7.5 Hz),

9.50 (1 H, s); ${ }^{13} \mathrm{C}$ NMR (125 MHz; d6-acetone) $\delta_{\mathrm{C}} 17.8,19.2,22.2,31.9,67.4,73.6,100.3,122.0$, 124.3, 125.6, 125.73, 125.75, 125.77, 125.80, 129.7, 131.0, 131.2, 131.4, 132.4, 134.4, 135.6, 136.75, 136.76, 137.6, 139.2, 142.7, 164.1, 164.5, 164.9, 165.3, 166.2; m/z found for $\mathrm{M}^{+}$(iminium cation) 292.1704; $\left[\mathrm{C}_{20} \mathrm{H}_{22} \mathrm{NO}\right]^{+}$requires 292.1701.

\section{$(a R, 3 R, 13 b S)-13 b-M e t h y l-3-p h e n y l-2,3-d i h y d r o-13 b H-d i b e n z[c, e]$ oxazolo[3,2-a]azepin-5-ium tetraphenylborate salt 8}

Compound 9 (0.43 g, $1.32 \mathrm{mmol}$ ) in dichloromethane (2 mL) and $N$-bromosuccinimide (0.47 g, 2.64 mmol, 2 equiv.) were treated using general procedure $C$ to yield the product as a pair of diastereoisomers (0.27 g, $0.66 \mathrm{mmol}, 50 \%)$; $v_{\max }(\mathrm{film}) / \mathrm{cm}^{-1}$ 3055, 1709, 1641, 1596, 1579, 1557, 1479, 1426, 1361, 1222, 731, 703. $[\alpha]^{20}{ }_{\mathrm{D}}-9.2^{\circ}$ (c 1.3, acetone). ${ }^{1} \mathrm{H}$ NMR (500 MHz; $d 6$-acetone) $\delta_{\mathrm{H}} 1.65$ (3 H, s), 4.85 (1 H, dd, J 5.0, $10.0 \mathrm{~Hz}$ ), 4.89 (1 H, dd, J 6.5, $10.0 \mathrm{~Hz}$ ), 5.79 (1 H, dt, J 1.0, 5.8 Hz), 6.72-6.77 (4 H, m), 6.88 (8 H, t, J 7.5 Hz), 7.28-7.34 (8 H, m), 7.57-7.60 (3 H, m), 7.68-7.72 (2 H, m), 7.72-7.75 (2 H, m), 7.80 (1 H, dt, $J$ 1.5, 7.5 Hz), 7.90 (2 H, dt, $J$ 1.5, 7.5 Hz), 7.95 (1 H, dd, $J$ 1.0, $8.0 \mathrm{~Hz}), 8.05$ (1 H, dt, $J$ 1.5, $8.0 \mathrm{~Hz}), 8.16$ (1 H, d, $J 7.5 \mathrm{~Hz}), 9.27(1 \mathrm{H}, \mathrm{d}, J 1.5 \mathrm{~Hz}) ;{ }^{13} \mathrm{C} \mathrm{NMR}$ (125 MHz; d6-acetone) $\delta_{\mathrm{C}}$ 21.4, 71.08, 71.15, 99.8, 121.4, 124.0, 125.1 (q, J 3Hz), 128.6, 128.8, 129.1, 129.9, 130.4, 130.6, 130.7, 130.9, 131.8, 135.6, 136.2 (q, J 1 Hz), 137.4, 142.5, 163.5, 163.9, 164.3, 164.7, 165.7. $\mathrm{m} / \mathrm{z}$ found for $\mathrm{M}^{+}$(iminium cation) 326.1549; $\left[\mathrm{C}_{23} \mathrm{H}_{20} \mathrm{NO}\right]^{+}$requires 326.1545 .

(aR,3R,13bS)-13b-Methyl-3-benzyl-2,3-dihydro-13bHdibenz[c,e]oxazolo[3,2-a]azepin-5-ium; tetraphenylborate salt 30 
Compound 26 (0.26 g, $0.80 \mathrm{mmol})$ in dichloromethane $(2 \mathrm{~mL})$ and $N$-bromosuccinimide $(0.29 \mathrm{~g}$, $1.60 \mathrm{mmol}$, 2 equiv.) were treated using general procedure $\mathrm{C}$ to yield the product $(0.28 \mathrm{~g}, 0.66 \mathrm{mmol}$, 82\%); $v_{\max }\left(\right.$ film) $/ \mathrm{cm}^{-1}$ 3051, 3013, 1642, 1598, 1581, 1557, 1481, 1426, 1381, 1183, 1031, 1016, 767, 755, 716, 714. $[\alpha]^{20}{ }_{\mathrm{D}}-30.3^{\circ}\left(\mathrm{c} 1.4, \mathrm{CHCl}_{3}\right) ;{ }^{1} \mathrm{H}$ NMR (500 MHz; d6-acetone) $\delta_{\mathrm{H}} 1.59$ (3 H, s), 3.61 (2 H, dq, $J$ 7.5, 13.5 Hz), 4.49 (1 H, dd, $J$ 5.0, 10.0 Hz), 4.66 (1 H, dd, $J$ 1.5, $10.0 \mathrm{~Hz}), 5.06-$ $5.13(1 \mathrm{H}, \mathrm{m}), 6.76$ (4 H, t, J 7.0 Hz), 6.91 (8 H, t, J 7.0 Hz), 7.30-7.35 (8 H, m), 7.44-7.52 (5 H, m), 7.70 (1 H, td, $J$ 1.5, $7.5 \mathrm{~Hz}), 7.71(1 \mathrm{H}, \mathrm{dd}, J$ 1.5, $8.0 \mathrm{~Hz}), 7.75(1 \mathrm{H}, \mathrm{td}, J$ 1.5, 7.5 Hz), $7.82(1 \mathrm{H}, \mathrm{td}$, $J$ 1.0, $8.0 \mathrm{~Hz}$ ), 7.85 (1 H, td, $J$ 1.5, $7.5 \mathrm{~Hz}), 7.89$ (1 H, dd, $J$ 1.5, $8.0 \mathrm{~Hz}), 8.08(1 \mathrm{H}, \mathrm{td}, J 1.5,7.5 \mathrm{~Hz})$, 8.16 (1 H, d, $J$ 7.5 Hz), 8.91 (1 H, s); ${ }^{13} \mathrm{C}$ NMR (125 MHz; d6-acetone) $\delta_{\mathrm{C}} 23.3,40.2,70.1,70.5$, 100.9, 122.2, 124.4, 125.5, 125.98, 126.00, 126.02, 126.04, 128.9, 130.0, 130.3, 130.9, 131.4, 131.5, 131.7, 132.7, 134.6, 135.3, 136.0, 137.04, 137.05, 138.0, 139.2, 143.0, 134.4, 164.8, 165.2, 165.5, 165.8; $\mathrm{m} / \mathrm{z}$ found for $\mathrm{M}^{+}$(iminium cation) 340.1707; $\left[\mathrm{C}_{24} \mathrm{H}_{22} \mathrm{NO}\right]^{+}$requires 340.17014 .

\section{(aS,3S,13bR)-13b-Methyl-3-benzyl-2,3-dihydro-13bHdibenz[c,e]oxazolo[3,2-a]azepin-5-ium, tetraphenylborate salt 31}

Compound 27 (0.51 g, $1.60 \mathrm{mmol})$ in dichloromethane $(5 \mathrm{~mL})$ and $N$-bromosuccinimide $(0.57 \mathrm{~g}$, $3.20 \mathrm{mmol}$, 2 equiv.) were treated using general procedure $\mathrm{C}$ to yield the product $(0.62 \mathrm{~g}, 1.20 \mathrm{mmol}$, 75\%); $v_{\max }\left(\right.$ film) /cm ${ }^{-1}$ 3445, 2358, 1714, 1654, 1616, 1558, 1454, 1404, 1257, 1182, 1104, 744, 701, 668; $[\alpha]^{20}{ }_{\mathrm{D}}+15.0^{\circ}$ (c 1.07, $\left.\mathrm{CHCl}_{3}\right) ;{ }^{1} \mathrm{H}$ NMR (400 MHz; d6-acetone) $\delta_{\mathrm{H}} 1.58$ (3 H, s), 3.58 (2 H, dq, $J$ 7.6, 13.6 Hz), 4.45 (1 H, dd, $J$ 5.2, $10.0 \mathrm{~Hz}), 4.62$ (1 H, dd, $J$ 1.2, $10.0 \mathrm{~Hz}), 4.98-5.06$ (1 H, m), 6.76 (4 H, t, J 7.2 Hz), 6.90 (8 H, t, J 7.6 Hz), 7.30-7.36 (8 H, m), 7.43-7.52 (5 H, m), 7.67 (1 H, dd, $J$ 1.2, 7.6 Hz), $7.70(1 \mathrm{H}, \mathrm{td}, J$ 1.6, $7.6 \mathrm{~Hz}), 7.75(1 \mathrm{H}, \mathrm{td}, J 1.6,7.6 \mathrm{~Hz}), 7.80(1 \mathrm{H}, \mathrm{td}, J 1.2,7.6 \mathrm{~Hz})$, 7.85 (1 H, td, $J$ 1.6, $8.0 \mathrm{~Hz}), 7.88$ (1 H, dd, $J$ 1.6, $7.6 \mathrm{~Hz}), 8.06$ (1 H, td, $J$ 1.2, $8.0 \mathrm{~Hz}), 8.14$ (1 H, d, $J$ $7.2 \mathrm{~Hz}), 8.84$ (1 H, s); ${ }^{13} \mathrm{C}$ NMR (125 MHz; d6-acetone) $\delta_{\mathrm{C}} 23.4,40.3,70.1,70.5,101.0,122.4$, 124.5, 125.5, 126.10, 126.12, 126.15, 126.18, 129.0, 130.1, 130.4, 131.0, 131.5, 131.6, 131.8, 132.8, 134.7, 135.5, 137.13, 137.15, 139.3, 143.1, 164.3, 164.8, 165.8, 165.9; m/z found for $\mathrm{M}^{+}$(iminium cation) 340.1701; $\left[\mathrm{C}_{24} \mathrm{H}_{22} \mathrm{NO}\right]^{+}$requires 340.1701.

\section{1-Phenylcyclohexene oxide ${ }^{24}$}

Isolated as a colourless oil: $v_{\max }\left(\right.$ neat) $/ \mathrm{cm}^{-1} 3083,1602,1495,1445,1359,1248,1174,1133,1078$, 1030, 993, 974; ${ }^{1} \mathrm{H}$ NMR (300 MHz; $\left.\mathrm{CDCl}_{3}\right) \delta_{\mathrm{H}}$ 1.20-1.33 (1 H, m), 1.51-1.62 (3 H, m), 1.97-2.05 (2 H, m), 2.16-2.18 (1 H, m), 2.24-2.31 (1 H, m), 3.10 (1 H, t, $J=2.0 \mathrm{~Hz}), 7.26-7.41(5 \mathrm{H}, \mathrm{m})$.

\section{1-Phenyldihydronaphthalene oxide ${ }^{24}$}


Isolated as a colourless crystalline solid: $v_{\max }\left(\right.$ neat)/ $\mathrm{cm}^{-1} 3087,1601,1493,1284,1176,1158,1094$, 1072, 1028; ${ }^{1} \mathrm{H}$ NMR (300 MHz; $\left.\mathrm{CDCl}_{3}\right) \delta_{\mathrm{H}} 2.10(1 \mathrm{H}, \mathrm{td}, J=15.5 \mathrm{~Hz}, 5.6 \mathrm{~Hz}) 2.48-2.59(1 \mathrm{H}, \mathrm{m})$, 2.76 (1 H, dd, $J=15.5$ Hz, 5.5 Hz) 2.96-3.07 (1 H, m), 3.70 (1 H, d, $J=3.0 \mathrm{~Hz}), 7.09-3.29$ (4 H, m), 7.45-7.60 (5 H, m). HPLC conditions-hexane/2-propanol (90:10), oven temp $20^{\circ} \mathrm{C}$, column Chiracel OD-H $01250 \times 4.6 \mathrm{~mm}, 5 \mu \mathrm{m}$ particle size, flow rate $1 \mathrm{~mL} / \mathrm{min}, 254 \mathrm{~nm}: t_{r}-4.51 \mathrm{~min}(-)-(1 S, 2 R)$, $5.94 \min (+)-(1 R, 2 S)$.

\section{(E)-Stilbene oxide ${ }^{24}$}

Isolated as a colourless crystalline solid: $v_{\max }\left(\right.$ neat) $/ \mathrm{cm}^{-1} 3081,1776,1602,1485,1336,1155,1074$, 1042, 953; ${ }^{1} \mathrm{H}$ NMR (400 MHz; $\left.\mathrm{CDCl}_{3}\right) \delta_{\mathrm{H}} 3.87$ (2 H, s), 7.29-7.39 (10 H, m); $\delta_{\mathrm{C}}\left(75 \mathrm{MHz} ; \mathrm{CDCl}_{3}\right)$ 63.3, 126.0, 128.6, 129.3, 137.6. HPLC conditions-hexane/2-propanol (80:20), oven temp $20{ }^{\circ} \mathrm{C}$, column Chiracel OD-H $01250 \times 4.6 \mathrm{~mm}, 5 \mu \mathrm{m}$ particle size, flow rate $1 \mathrm{~mL} / \mathrm{min}, 254 \mathrm{~nm}: t_{r}-4.98$ $\min (-)-(1 S, 2 S), 6.54 \min (+)-(1 R, 2 R)$.

\section{Dihydronaphthalene oxide ${ }^{8}$}

Isolated as a colourless oil: $v_{\max }\left(\right.$ neat)/ $\mathrm{cm}^{-1}$ 3058, 3028, 2931, 2850, 1602, 1492, 1314, 1129, 1088, 1031, 965; ${ }^{1} \mathrm{H}$ NMR (400 MHz; $\mathrm{CDCl}_{3}$ ) $\delta_{\mathrm{H}}$ 1.65-1.84 (1 H, m), 2.33-2.42 (1 H, m), 2.52 (1 H, dd, $J$ = 15.5 Hz, 5.5 Hz), 2.67-2.85 (1 H, m), 3.71-3.80 (1 H, m), 3.81-3.89 (1 H, m), 7.05 (1 H, d, J = 7.2 Hz), 7.18-7.35 (2 H, m), 7.40 (1 H, d, $J=7.1 \mathrm{~Hz})$.

\section{Triphenylethylene oxide ${ }^{8}$}

Isolated as a colourless crystalline solid: $v_{\max }\left(\right.$ neat) $/ \mathrm{cm}^{-1}$ 3061, 3031, 2956, 2924, 2857, 1604, 1595, 1498, 1471, 1448, 1262, 1220, 741, 699; ${ }^{1} \mathrm{H}$ NMR (400 MHz; $\left.\mathrm{CDCl}_{3}\right) \delta_{\mathrm{H}} 4.42$ (1 H, s), 7.13- 5.50 (15H, m). HPLC conditions-hexane/2-propanol (90:10), oven temp $20{ }^{\circ} \mathrm{C}$, column Chiracel OD-H $01250 \times 4.6 \mathrm{~mm}, 5 \mu \mathrm{m}$ particle size, flow rate $1 \mathrm{~mL} / \mathrm{min}, 254 \mathrm{~nm}: t_{r}-4.26 \mathrm{~min}(+)-(S), 7.47 \mathrm{~min}(-$ )$-(R)$.

\section{Crystallography}

For 9 and 27 diffraction data were collected at 150(2)K and corrections were made for absorption, Lorentz, and polarization factors. Both structures were solved by direct methods and were routine in nature. The absolute structures could not be determined reliably from the diffraction data, so were set from unchanging chiral centres. For 9: $\mathrm{C}_{23} \mathrm{H}_{21} \mathrm{NO}, \mathrm{M}=327.41$, monoclinic, $P 2_{1}, a=8.4016(5), b=$ 9.9253(6), $c=10.5431(7) \AA \AA, \beta=97.2928(9)^{\circ}, V=872.06(9) \AA^{3}, Z=2$, colourless crystal, $0.32 \times$ $0.29 \times 0.10 \mathrm{~mm}^{3}, D_{\text {calc }}=1.247 \mathrm{~g} / \mathrm{cm}^{3}, \mu(\mathrm{Mo}-\mathrm{K} \alpha)=0.076 \mathrm{~mm}^{-1}, 9089$ data measured, $R_{\text {int }}=0.020$, 
$w R_{2}=0.090$ for all 4258 unique data, $R 1=0.037$ for 3932 data with $F^{2} \geq 2 \sigma\left(F^{2}\right)$. For 27: $\mathrm{C}_{24} \mathrm{H}_{23} \mathrm{NO}$, $\mathrm{M}=341.43$, monoclinic, $P 2_{1}, a=8.5648(4), b=9.8551(5), c=11.1777(5) \AA, \beta=98.4207(7)^{\circ}, V=$ 933.30(8) $\AA^{3}, Z=2$, colourless crystal, $0.52 \times 0.38 \times 0.36 \mathrm{~mm}^{3}, D_{\text {calc }}=1.247 \mathrm{~g} / \mathrm{cm}^{3}, \mu(\mathrm{Mo}-\mathrm{K \alpha} \alpha)=$ $0.073 \mathrm{~mm}^{-1}, 11151$ data measured, $R_{\mathrm{int}}=0.022, w R_{2}=0.119$ for all 5541 unique data, $R 1=0.044$ for 4987 data with $F^{2} \geq 2 \sigma\left(F^{2}\right)$. CCDC 1400420-1400421 contain supplementary crystallographic data in cif format. These data can be obtained free of charge via www.ccdc.cam.ac.uk/conts/retrieving.html (or from the CCDC, 12 Union Road, Cambridge, CB2 1EZ, UK. Fax +44 1223 336033, e-mail: deposit@ccdc.cam.ac.uk.).

\section{Acknowledgments}

This investigation has enjoyed the support of Loughborough University, the EPSRC, the University of East Anglia, and the ERDF (ISCE-Chem \& INTERREG IVa programme 4061). We are indebted to the Royal Society for an Industry Fellowship (to PCBP) and the EPSRC national mass spectrometry service at the University of Wales, Swansea.

\section{Supporting Information}

Supporting Information: ${ }^{1} \mathrm{H}$ and ${ }^{13} \mathrm{C}$ NMR spectra; Displacement ellipsoid plots of 9 and 27. This material is available free of charge via the Internet at http://pubs.acs.org/.

\section{References}

1) (a) Behrens, C.H.; Sharpless, K. B. Aldrichimica Acta 1983, 16, 67; (b) Gorzynski Smith, J. Synthesis 1984, 629; (c) Katsuki, T. Coord. Chem. Rev. 1995, 140, 189; (d) Paquette, L. A.; Gao, Z.; Ni, Z.; Smith, G. F. J. Am. Chem. Soc. 1998, 120, 2543; (e) Amano, S.; Ogawa, N.; Ohtsuka, M.; Chinda, N. Tetrahedron 1999, 55, 2205; (f) Wong, O. A.; Shi, Y. Chem. Rev. 2008, 108, 3958.

2) See for example: (a) Johnson, R. A.; Sharpless, K. B. In Catalytic Asymmetric Synthesis, Ojima, I., Ed.; VCH: New York, 1993; (b) Katsuki, T. In Comprehensive Asymmetric Catalysis, Jacobsen, E. N., Pfaltz, A., Yamamoto, H., Eds., Springer: Berlin, 1999, Vol. 2, p 621.; (c) Jacobsen, E. N.; Wu, M.H. In Comprehensive Asymmetric Catalysis, Jacobsen, E. N.; Pfaltz, A.; Yamamoto, H., Eds.; Springer: Berlin, 1999; Vol. 2, p 649; (d) Julia, S.; Masana, J.; Vega, J. C. Angew. Chem. Int. Ed. Engl. 1980, 19, 929; (e) Allen, J. V.; Bergeron, S.; Griffiths, M. J.; Mukherjee, S.; Roberts, S. M.; Williamson, N. M.; Wu, L. E. J. Chem. Soc., Perkin Trans. 1 1998, 3171; (f) Katsuki, T.; Sharpless, K. B. J. Am. Chem Soc. 1980, 102, 5974; (g) Michaelson, R. C; Palermo, R. E.; Sharpless, K. B. J Am. Chem. Soc. 
1977, 99, 1990; (h) Groves, J. T.; Nemo, T. E.; Myers, R. S. J. Am. Chem. Soc., 1979, 101, 1032; (i) Groves, J. T.; Myers, R. S. J. Am. Chem. Soc., 1983, 105, 5791; (j) Cavallo, L.; Jacobsen, H. Inorg. Chem. 2004, 43, 2175; (k) Irie, R.; Noda, K.; Ito, Y.; Matsumoto, N.; Katsuki, T. Tetrahedron Lett. 1990, 31, 7345; (l) Kawai, H.; Okusu, S.; Yuan, Z.; Tokunaga, E.; Yamano, A.; Shiro, M.; Shibata, M. Angew. Chem. Int. Ed. 2013, 52, 2221.

3) See for example; (a) Tu, Y.; Wang, Z.-X.; Shi, Y. J. Am. Chem. Soc. 1996, 118, 9806; (b) Wang, Z.-X.; Tu, Y.; Frohn, M.; Shi, Y. J. Org. Chem. 1997, 62, 2328; (c) Wang, Z.-X.; Shi, Y. J. Org. Chem. 1998, 63, 3099; (d) Wang, Z.-X.; Shi, Y. J. Org. Chem. 1997, 62, 8622; (e) Cao, G. A.; Wang, Z.-X.; Tu, Y.; Shi, Y. Tetrahedron Lett. 1998, 39, 4425; (f) Zhu, Y.; Tu, Y.; Yu, H.; Shi, Y. Tetrahedron Lett. 1998, 39, 7819; (g) Yong, T.; Wang, Z. X.; Frohn, M.; He, M.; Yu, H.; Tang, Y.; Shi, Y. J. Org. Chem. 1998, 63, 8475; (h) Warren, J. D.; Shi, Y. J. Org. Chem. 1999, 64, 7675; (i) Frohn, M.; Zhou, X.; Zhang, J.-R.; Tang, Y.; Shi, Y. J. Am. Chem. Soc. 1999, 121, 7718; (j) Shu, L.; Shi, Y. Tetrahedron Lett. 1999, 40, 8721; (k) Shu, L.; Shi, Y. J. Org. Chem. 2000, 65, 8807; (l) Tian, H.; She, X.; Xu, J.; Shi, Y. Org. Lett. 2001, 3, 1929; (m) Tian, H.; She, X.; Yu, H.; Shu, L.; Shi, Y. J. Org. Chem. 2002, 67, 2435; (n) Wu, X.-Y.; She, X.; Shi, Y. J. Am. Chem. Soc. 2002, 124, 8792; (o) Denmark, S. E.; Wu, Z. Synlett 1999, 847; (p) Denmark, S. E.; Forbes, D. C.; Hays, D. S.; DePue, J. S.; Wilde, R. G. J. Org. Chem. 1995, 60, 1391; (q) Denmark, S. E.; Matsuhashi, H. J. Org. Chem. 2002, 67, 3479; (r) Yang, D.; Yip, Y.-C.; Tang, M.-W.; Wong, M.-K.; Zheng, J.-H.; Cheung, K.-K. J. Am. Chem. Soc. 1996, 118, 491; (s) Yang, D.; Wang, X. C.; Wong, M.-K.; Yip, Y.-C.; Tang, M.-W. J. Am. Chem. Soc. 1996, 118, 11311; (t) Yang, D.; Wong, M.-K.; Yip, Y.-C.; Wang, X. C.; Tang, M.-W.; Zheng, J.-H.; Cheung, K.-K. J. Am. Chem. Soc. 1998, 120, 5943; (u) Yang, D.; Yip, M. C.; Tang, M. M.; Wong, M. K.; Cheung, K. K. J. Org. Chem. 1998, 63, 9888; (v) Armstrong, A.; Hayter, B. R. Chem. Commun. 1998, 621; (w) Armstrong, A.; Ahmed, G.; Dominguez-Fernandez, B.; Hayter, B. R.; Wailes, J. S. J. Org. Chem. 2002, 67, 8610; (x) Curci, R.; Fiorentino, M.; Serio, M. R. Chem. Commun. 1984, 155.

4) Picot, A.; Milliet, P.; Lusinchi, X. Tetrahedron Lett. 1976, 17, 1573; Milliet, P.; Picot, A.; Lusinchi, X. Tetrahedron Lett. 1976, 17, 1577.

5) (a) Hanquet, G.; Lusinchi, X.; Milliet, P. Tetrahedron Lett., 1987, 28, 6061; (b) Hanquet, G.; Lusinchi, X.; Milliet, P. Tetrahedron Lett. 1988, 29, 3941; (c) Bohé, L.; Hanquet, G.; Lusinchi, M.; Lusinchi, X. Tetrahedron Lett. 1993, 34, 7271; (d) Bohé, L.; Lusinchi, M.; Lusinchi, X. Tetrahedron, 1999, 55, 141; (e) Lacour, J.; Monchaud, D.; Marsol, C. Tetrahedron Lett. 2002, 43, 8257; (f) Bohé, L.; Kammoun, M. Tetrahedron Lett. 2002, 43, 803; g) Bohé, L.; Kammoun, M. Tetrahedron Lett. 2004, 45, 747; (h) Aggarwal, V. K.; Wang, M. F. Chem. Commun. 1996, 191; (i) Armstrong, A.; Ahmed, G.; Garnett, I.; 
Gioacolou, K. Synlett 1997, 1075; (j) Armstrong, A.; Ahmed, G.; Garnett, I.; Gioacolou K.; Wailes, J. S. Tetrahedron 1999, 55, 2341; (k) Gluszynska, A.; Mackowska, I.; Rozwadowska, M. D.; Sienniak, W. Tetrahedron: Asymmetry 2004, 15, 2499; (l) Biscoe, M. R.; Breslow R. J. Am. Chem. Soc. 2005, 127, 10812; (m) Minakata, S.; Takemiya, A.; Nakamura, K.; Ryu, I.; Komatsu, M. Synlett, 2000, 1810; (n) Wong, M.-K.; Ho, L.-M.; Zheng, Y.-S.; Ho, C.-Y.; Yang, D. Org. Lett. 2001, 16, 2587; (o) Crosthwaite, J. M.; Farmer, V. A.; Hallett, J. P.; Welton, T. J. Mol. Catal. A 2008, 279, 148; (p) Novikov, R.; Lacour, J. Tetrahedron: Asymmetry 2010, 21, 1611; (q) Novikov, R.; Vachon, J.; Lacour, J. Chimia, 2007, 61, 236; (r) Vachon, J.; Lauper, C.; Ditrich, K.; Lacour, J. Tetrahedron: Asymmetry 2006, 17, 2334; (s) Vachon, J.; Rentsch, S.; Martinez, A.; Marsol, C.; Lacour, J. Org. Biomol. Chem. 2007, 5, 501; (t) Novikov, R.; Bernardinelli, G.; Lacour, J. Adv. Synth. Catal. 2009, 351, 596.

6) (a) Gonçalves, M.-H.; Martinez, A.; Grass, S.; Bulman Page, P. C.; Lacour, J. Tetrahedron Lett. 2006, 47, 5297; (b) Adamo, M. F. A.; Aggarwal, V. K.; Sage, M. A. J. Am. Chem. Soc. 2000, 122, 8317; (c) Adamo, M. F. A.; Aggarwal, V. K.; Sage, M. A. J. Am. Chem. Soc. 2002, 124, 11223; (d) Aggarwal, V. K.; Lopin, C.; Sandrinelli, F. J. Am. Chem. Soc. 2003, 125, 7596; (e) Ho, C.-Y.; Chen, Y.-C.; Wong, M.-K.; Yang, D. J. Org. Chem. 2005, 70, 898.

7) Farah, M. M.; Page, P. C. B.; Buckley, B. R.; Blacker, A. J.; Elsegood, M. R. J. Tetrahedron 2013, 69, 758.

8) (a) Page, P. C. B.; Buckley, B. R.; Farah, M. M.; Blacker, A. J. Eur. J. Org. Chem. 2009, 3413; (b) Page, P. C. B.; Bartlett, C. J.; Chan, Y.; Day, D. P.; Parker, P.; Buckley, B. R.; Rassias, G. A.; Slawin, A. M. Z.; Allin, S. M.; Lacour, J.; Pinto, A. J. Org. Chem. 2012, 77, 6128.

9) (a) Bulman Page, P. C.; Parker, P.; Buckley, B. R.; Rassias, G. A.; Bethell, D. Tetrahedron, 2009, 65, 2910; (b) Buckley, B. R.; Chan, Y.; Dreyfus, N.; Elliott, C. E.; Marken, F.; Page, P. C. B. Green Chem. 2012, 14, 2221 and references therein; (c) Buckley, B. R.; Elliott, C. E.; Chan, Y.; Dreyfus, N.; Bulman Page, P. C. Synlett, 2013, 2266 and references therein.

10) Campestrini, S.; Di Furia, F.; Labat, G.; Novello, F. J. Chem. Soc. Perkin Trans. 2 1994, 10, 2175.

11) (a) Page, P. C. B.; Buckley, B. R.; Barros, D.; Blacker, J. A.; Marples, B. A.; Elsegood, M. R. J. Tetrahedron. 2007, 63, 5386; (b) Bartlett, C. J.; Day, D. P.; Chan, Y.; Allin, S. M.; McKenzie, M. J.; Slawin, A. M. Z.; Bulman Page, P. C. J. Org. Chem. 2012, 77, 772; (c) Bulman Page, P. C.; Appleby, L. F.; Chan, Y.; Day, D.; Buckley, B. R.; Slawin, A. M. Z.; Allin, S. M.; McKenzie, M. J. J. Org. Chem. 2013, 78, 8074; (d) Page, P. C. B.; Chan, Y.; Day, D. P.; Eur. J. Org. Chem., 2014, 8029. 
12) (a) Bringmann, G.; Price Mortimer, A. J.; Keller, P. A.; Gresser, M. J.; Garner, J.; Breuning, M. Angew. Chem. Int. Ed. 2005, 44, 5384; (b) Baudoin, O. Eur. J. Org. Chem. 2005, 4223;

(c) Wallace, T. W. Org. Biomol. Chem. 2006, 4, 3197.

13) Wallace, T. W; Pira, S. L.; Graham, J. P. Org. Lett. 2009, 11, 1663.

14) Novikov, R.; Bernardinelli, G.; Lacour, J. Adv. Synth. Catal. 2008, 350, 1113.

15) Bulman Page, P. C.; Bartlett, C. J.; Chan, Y.; Day, D.; Parker, P.; Buckley, B. R.; Rassias, G. A.; Slawin, A. M. Z.; Allin, S. M.; Lacour, J.; Pinto, A. J. Org. Chem. 2012, 77, 6128.

16) (a) Meyers, A. I.; Brengel, G. P. Chem. Commun. 1997, 1; (b) Amat, M.; Canto, M.; Llor, N.; Ponzo, V.; Perez, M.; Bosch, J. Angew. Chem., Int. Ed. 2002, 41, 335; (c) Amat, M.; Canto, M.; Llor, N.; Escolano, C.; Molins, E.; Espinosa, E.; Bosch, J. J. Org. Chem. 2002, 67, 5343; (d) Amat, M.; Llor, N.; Hidalgo, J.; Escolano, C.; Bosch, J. J. Org. Chem. 2003, 68, 1919; (e) Ennis, M. D.; Hoffman R. L.; Ghazal, N. B.; Old, D. W.; Mooney, P. A. J. Org. Chem. 1996, 61, 5813; (f) Allin, S. M.; James, S. L.; Elsegood, M. R. J.; Martin, W. P. J. Org. Chem. 2002, 67, 9464; (g) Houpis, J. N.; Molina, A.; Reamer, R. A.; Joseph, J. E.; Volante, R. P.; Reider, P. J. Tetrahedron Lett. 1993, 34, 2593; (h) Penhoat, M.; Leleu, S.; Dupas, G.; Papamicaël, C.; Marsais, F.; Levacher, V. Tetrahedron Lett. 2005, 46, 8385; (i) Husain, S. M.; Heim, M. T.; Schepmann, D.; Wünsch, B. Tetrahedron: Asymmetry, 2009, 20, 1383; (j) Penhoat, M.; Bohn, P.; Dupas, G.; Papamicaël, C.; Marsais, F.; Levacher, V. Tetrahedron: Asymmetry, 2006, 17, 281; (k) Husain, S. M.; Fröhlich, R.; Wünsch B. Tetrahedron: Asymmetry, 2008, 19, 1613; (l) Bouet, A.; Oudeyer, S.; Dupas, G.; Marsais, F.; Levacher, V. Tetrahedron: Asymmetry, 2008, 19, 2396.

17) (a) Penhoat, M.; Levacher, V.; Dupas, G. J. Org. Chem. 2003, 68, 9517; (b) Ried, W.; Conte, R. Chem. Ber. 1971, 104, 1573; (c) Edwards, D. J.; Pritchard, R. G.; Wallace, T. W. Tetrahedron Lett. 2003, 44, 4665; (d) Edwards, D. J.; House, D.; Sheldrake, H. M.; Stone, S. J.; Wallace, T. W. Org. Biomol. Chem. 2007, 5, 2658; (e) Postikova, S.; Sabbah, M.; Wightman, D.; Nguyen, I. T.; Sanselme, M.; Besson, T.; Brière, J.-F.; Oudeyer, S.; Levacher, V. J. Org. Chem. 2013, 78, 8191.

18) (a) Burgess, L. E.; Meyers, A. I. J. Org. Chem. 1992, 57, 1656; (b) Meyers, A. I.; Sowning, S. V.; Weiser, M. J. J. Org. Chem. 2001, 66, 1413; (c) Husain, S. M.; Fröhlich, R.; Schepmann, D.; Wünsch, B. J. Org. Chem. 2009, 74, 2788; (d) Wallace, T. W; Pira, S. L.; Graham, J. P. Org. Lett. 2009, 11, 1663.

19) (a) Campeau, L.-C.; Parisien, M.; Leblanc, M.; Fagnou, K. J. Am. Chem. Soc. 2004, 126, 9186; (b) Leblanc, M.; Fagnou, K. Org. Lett. 2005, 7, 2849; (c) Lafrance, M.; Lapointe, D.; Fagnou, K. Tetrahedron, 2008, 64, 6015.

20) Cheetham, C. A.; Massey, R. S.; Pira, S. L.; Pritchard, R. G.; Wallace, T. W. Org. Biomol. 
Chem. 2011, 9, 1831.

21) Bulman Page, P. C.; Farah, M. M.; Buckley, B. R.; Blacker, A. J.; Lacour, J. Synlett, 2008, 1381.

22) APEX 2 and SAINT (2006), software for CCD diffractometers. Bruker AXS Inc., Madison, USA.

23) (a) Sheldrick, G. M. Acta Cryst., 2015, C71, 3; (b) Sheldrick, G. M. SHELXTL user manual, version 6.12. Bruker AXS Inc., Madison, WI, USA, 2001.

24) Bulman Page, P. C.; Rassias, G. A.; Bethell, D.; Schilling, M. B. J. Org. Chem. 1998, 63, 2774. 
TOC Graphic

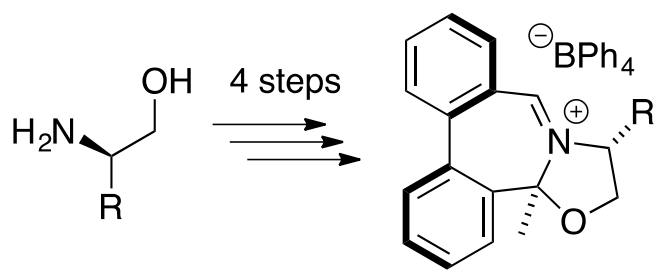<smiles>[R]C=C([R])[R]</smiles>

Iminium salts obtained as Up to $76 \%$ ee single atropo- and diastereoisomers 